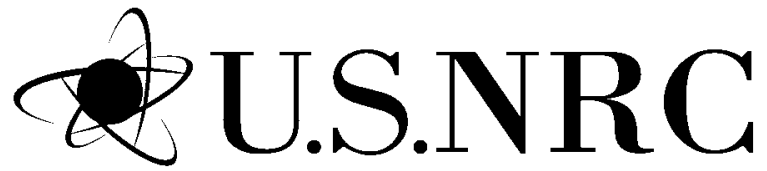

United States Nuclear Regulatory Commission

Protecting People and the Environment

\title{
Bias Estimates Used in Lieu of Validation of Fission Products and Minor Actinides in MCNP Keff Calculations for PWR Burnup Credit Casks
}




\section{AVAILABILITY OF REFERENCE MATERIALS IN NRC PUBLICATIONS}

\section{NRC Reference Material}

As of November 1999, you may electronically access NUREG-series publications and other NRC records at NRC's Library at www.nrc.gov/reading-rm.html. Publicly released records include, to name a few, NUREG-series publications; Federal Register notices; applicant, licensee, and vendor documents and correspondence; NRC correspondence and internal memoranda; bulletins and information notices; inspection and investigative reports; licensee event reports; and Commission papers and their attachments.

NRC publications in the NUREG series, NRC regulations, and Title 10, "Energy," in the Code of Federal Regulations may also be purchased from one of these two sources.

1. The Superintendent of Documents

U.S. Government Publishing Office

Mail Stop IDCC

Washington, DC 20402-0001

Internet: bookstore.gpo.gov

Telephone: (202) 512-1800

Fax: (202) 512-2104

2. The National Technical Information Service 5301 Shawnee Rd., Alexandria, VA 22312-0002 www.ntis.gov

1-800-553-6847 or, locally, (703) 605-6000

A single copy of each NRC draft report for comment is available free, to the extent of supply, upon written request as follows:

\section{Address: U.S. Nuclear Regulatory Commission \\ Office of Administration \\ Publications Branch \\ Washington, DC 20555-0001 \\ E-mail: distribution.resource@nrc.gov \\ Facsimile: (301) 415-2289}

Some publications in the NUREG series that are posted at NRC's Web site address www.nrc.gov/reading-rm/ doc-collections/nuregs are updated periodically and may differ from the last printed version. Although references to material found on a Web site bear the date the material was accessed, the material available on the date cited may subsequently be removed from the site.

\section{Non-NRC Reference Material}

Documents available from public and special technical libraries include all open literature items, such as books, journal articles, transactions, Federal Register notices, Federal and State legislation, and congressional reports. Such documents as theses, dissertations, foreign reports and translations, and non-NRC conference proceedings may be purchased from their sponsoring organization.

Copies of industry codes and standards used in a substantive manner in the NRC regulatory process are maintained at-

The NRC Technical Library

Two White Flint North

11545 Rockville Pike

Rockville, MD 20852-2738

These standards are available in the library for reference use by the public. Codes and standards are usually copyrighted and may be purchased from the originating organization or, if they are American National Standards, from-
American National Standards Institute
11 West 42nd Street
New York, NY 10036-8002
www.ansi.org
(212) 642-4900

Legally binding regulatory requirements are stated only in laws; NRC regulations; licenses, including technical specifications; or orders, not in NUREG-series publications. The views expressed in contractorprepared publications in this series are not necessarily those of the NRC.

The NUREG series comprises (1) technical and administrative reports and books prepared by the staff (NUREG$X X X X)$ or agency contractors (NUREG/CR-XXXX), (2) proceedings of conferences (NUREG/CP-XXXX), (3) reports resulting from international agreements (NUREG/IA-XXXX), (4) brochures (NUREG/BR-XXXX), and (5) compilations of legal decisions and orders of the Commission and Atomic and Safety Licensing Boards and of Directors' decisions under Section 2.206 of NRC's regulations (NUREG-0750).

DISCLAIMER: This report was prepared as an account of work sponsored by an agency of the U.S. Government. Neither the U.S. Government nor any agency thereof, nor any employee, makes any warranty, expressed or implied, or assumes any legal liability or responsibility for any third party's use, or the results of such use, of any information, apparatus, product, or process disclosed in this publication, or represents that its use by such third party would not infringe privately owned rights. 
United States Nuclear Regulatory Commission

Protecting People and the Environment

\section{Bias Estimates Used in Lieu of Validation of Fission Products and Minor Actinides in MCNP Keff Calculations for PWR Burnup Credit Casks}

Manuscript Completed: May 2014

Date Published: September 2015

Prepared by:

D. E. Mueller, W. J. Marshall, D. G. Bowen, and J. C. Wagner

Oak Ridge National Laboratory

Managed by UT-Battelle, LLC

Oak Ridge, TN 37831-6170

A. Barto, Project Manager

NRC Job Code J5728

Office of Nuclear Material Safety and Safeguards 



\begin{abstract}
The U.S. Nuclear Regulatory Commission Division of Spent Fuel Management issued Interim Staff Guidance (ISG) 8, Revision 3 in September 2012. This ISG provides guidance for NRC Staff review of burnup credit analyses supporting transport and dry storage of pressurized water reactor spent nuclear fuel (SNF) in casks. ISG-8, Rev. 3 includes, among other things, guidance for addressing validation of criticality $\left(k_{\text {eff }}\right)$ calculations crediting the presence of a limited set of fission products and minor actinides (FP\&MA). Based on previous work documented in NUREG/CR-7109, ISG-8, Rev. 3 includes a recommendation to accept use of 1.5 or $3 \%$ of the FP\&MA worth, depending on the criticality code and cross-section data used, to conservatively account for the bias and bias uncertainty associated with the selected insufficiently validated FP\&MAs. This bias is applied in addition to the bias and bias uncertainty resulting from validation of $k_{\text {eff }}$ calculations for the major actinides in SNF. The work described in this report involves comparison of FP\&MA worths calculated using SCALE and Monte Carlo N-Particle (MCNP) with Evaluated Nuclear Data Files, Part B-V, $-\mathrm{VI}$, and -VII based nuclear data. The comparison supports use of the 1.5\% FP\&MA worth bias when either SCALE or MCNP codes are used for criticality calculations, provided the other conditions of ISG-8, Rev. 3,

Recommendation 4 are met. The additional conditions include that the cask design is similar to the hypothetical generic burnup credit-32 cask model and that the credited FP\&MA worth is no more than $0.1 \Delta k_{\text {eff }}$
\end{abstract}





\section{TABLE OF CONTENTS}

Section

Page

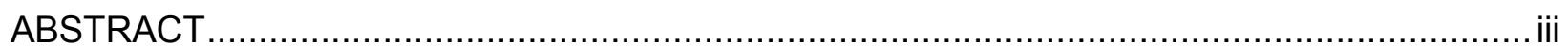

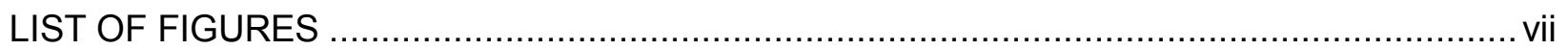

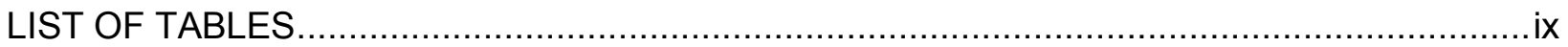

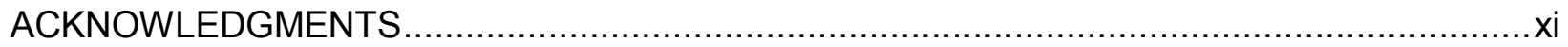

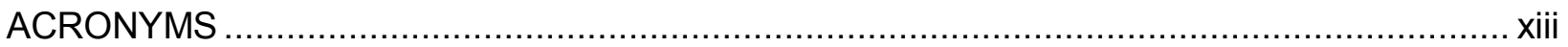

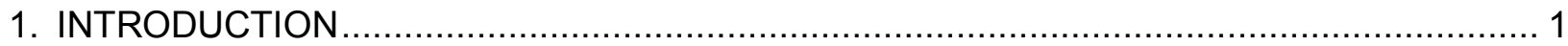

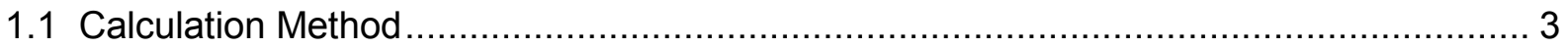

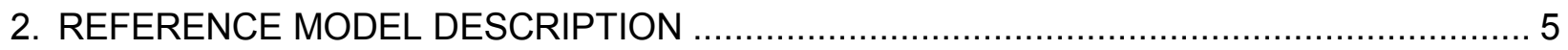

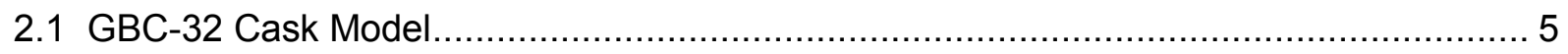

2.2 PWR Fuel Assembly Specification..............................................................11

2.3 Reference Model Fuel Compositions ........................................................11

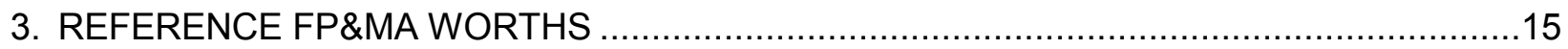

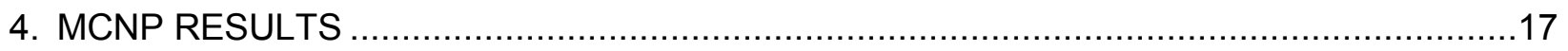

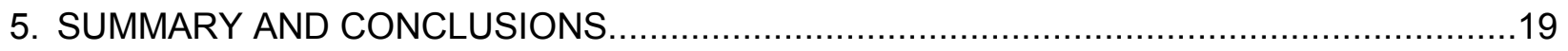

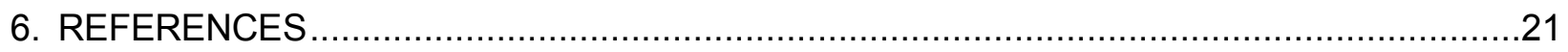

APPENDIX A. SCALE 6.1 CSAS5 MODEL …......................................................... A-1

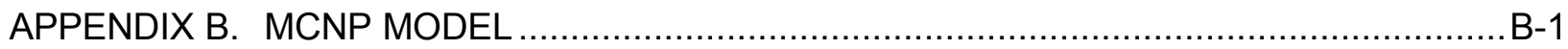

APPENDIX C. DETAILED FP\&MA WORTH RESULTS FOR EACH CODE AND

NUCLEAR DATA COMBINATION ...................................................... 



\section{LIST OF FIGURES}

\section{Figure}

Page

Figure 2.1. Radial cross section of one quarter of the GBC-32 cask. 8

Figure 2.2. Cross-sectional view of an assembly cell in KENO V.a model for the

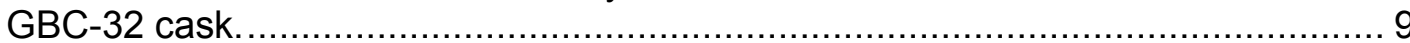

Figure 2.3. Isometric view of GBC-32 cask with top and front halves removed......................10

Figure 2.4. Burnup credit loading curves for the GBC-32 application models. ......................12 



\section{LIST OF TABLES}

Table

Page

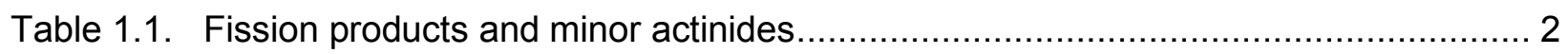

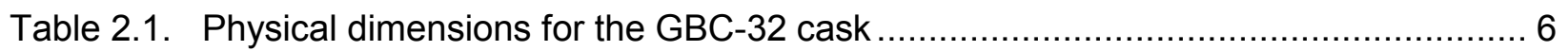

Table 2.2. Material compositions for GBC-32 cask model ........................................... 7

Table 2.3. PWR fuel assembly specifications ......................................................... 11

Table 2.4. Burned fuel compositions for reference FP\&MA worth calculations ......................13

Table 3.1. Reference FP\&MA worth results using SCALE 6.1 and the ENDF/B-VII

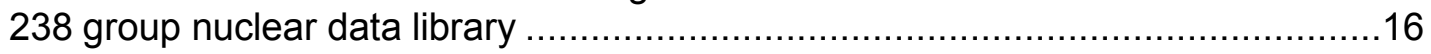

Table 4.1. Variation in calculated FP\&MA worths using various codes and data ...................17

Table C.1. FP\&MA worths using SCALE 6.1 and ENDF/B-VII continuous-energy data ........C-1

Table C.2. FP\&MA worths using SCALE 6.1 and ENDF/B-VI 238 energy group data ..........C-2

Table C.3. FP\&MA worths using SCALE 6.1 and ENDF/B-V 238 energy group data ...........C-3

Table C.4. FP\&MA worths using SCALE 6.1 and ENDF/B-V 44 energy group data ..............4

Table C.5. FP\&MA worths using MCNP5 (version 1.60) and ENDF/B-VII data................... -5

Table C.6. FP\&MA worths using MCNP5 (version 1.60) and ENDF/B-VI data....................6

Table C.7. FP\&MA worths using MCNP5 (version 1.60) and ENDF/B-V data.....................7

Table C.8. FP\&MA worths using MCNP6 (new release) and ENDF/B-V data.....................8

Table C.9. FP\&MA worths using MCNP6 (new release) and ENDF/B-VI data.....................9

Table C.10. FP\&MA worths using MCNP6 (new release) and ENDF/B-VII data..................-10

Table C.11. FP\&MA worths using MCNP6 (new release) and ENDF/B-VII.1 data............... -11 



\section{ACKNOWLEDGMENTS}

This work was performed under contract with the Division of Spent Fuel Management, U.S. Nuclear Regulatory Commission. The authors thank A. Barto, the NRC Project Manager, and Z. $\mathrm{Li}$ and V. Wilson of the Office of Nuclear Material Safety and Safeguards for their support and guidance. The careful reviews of the draft manuscript by J. M. Scaglione and J. B. Clarity are very much appreciated. Finally, the authors are thankful to D. J. Weaver for her preparation of the final report. 



\section{ACRONYMS}

$\begin{array}{ll}\text { BUC } & \text { burnup credit } \\ \text { CENTRM } & \text { continuous energy transport module } \\ \text { CSAS } & \text { Criticality Safety Analysis Sequence } \\ \text { ENDF/B } & \text { Evaluated Nuclear Data Files, Part B } \\ \text { FP } & \text { fission products } \\ \text { FP\&MA } & \text { fission products and minor actinides } \\ \text { GBC } & \text { generic burnup credit cask; as in GBC-32, a generic burnup credit cask } \\ \text { GWd/MTU } & \text { model with a 32 PWR fuel assembly capacity } \\ \text { ISG } & \text { unit of nuclear fuel burnup; gigawatt-days per initial metric ton of uranium } \\ k_{\text {eff }} & \text { interim staff guidance } \\ \text { MA } & \text { effective neutron multiplication factor } \\ \text { MCNP } & \text { minor actinides } \\ \text { NRC } & \text { Monte Carlo N-Particle } \\ \text { NUREG/CR } & \text { U.S. Nuclear Regulatory Commission } \\ \text { OFA } & \text { Publications prepared by NRC Contractors } \\ \text { ORNL } & \text { optimized fuel assembly; as in Westinghouse 17 × 17 OFA } \\ \text { PWR } & \text { Oak Ridge National Laboratory } \\ \text { SNF } & \text { pressurized water reactor } \\ & \text { spent nuclear fuel }\end{array}$





\section{INTRODUCTION}

The concept of taking credit for the reduction in reactivity resulting from the net consumption of fissile nuclides and creation of neutron absorbing actinides and fission products during reactor operation is commonly referred to as "burnup credit" (BUC). The analysis supporting BUC requires two different types of computer calculations. First, the analyst uses a computer code to generate spent nuclear fuel (SNF) compositions based on conditions experienced by the fuel assemblies in the reactor. The spent fuel compositions are then typically used in threedimensional Monte Carlo method neutron transport calculations to determine the $k_{\text {eff }}$ values for the system loaded with SNF. The combination of the computer codes, nuclear data, computational input options used, and modeling approximations used is referred to as the "computational method."

Computational method validation is used to quantify the relationship between calculated values and reality and is performed by comparing results, calculated using the computational method, to measured or expected results. For example, the computational method would be used to model a set of laboratory critical experiments, yielding calculated estimates for the neutron multiplication factor $\left(k_{\text {eff }}\right)$. Appropriate statistical techniques are applied to the calculated and expected $k_{\text {eff }}$ values to determine the bias and bias uncertainty associated with the computational method.

Use of the same computational method in both the safety analysis and the validation study enables the analyst to quantify the bias and bias uncertainty associated with the computational method. However, the accuracy of the calculated bias and bias uncertainty is also dependent on the degree of similarity between the safety analysis models and the critical experiments. If materials are present in either the safety analysis models or critical experiments and not in the other, any bias associated with these materials may not be captured correctly by the validation study. Bias errors also can be introduced when a material is present in both but has a different effect on $k_{\text {eff. }}$ The same nuclear data errors then affect the $k_{\text {eff }}$ of the safety analysis models and critical experiments differently, resulting in different $k_{\text {eff }}$ biases. Such differences may result from factors such as shifts in the neutron energy spectrum to higher or lower energies or because of spatial variation of the neutron flux.

Burnup credit analyses for storage and transportation casks frequently seek to take credit for some fission products (FP) and actinides for which little or no appropriate critical experiment data are available for use in validation studies. At the U.S. Nuclear Regulatory Commission's (NRC's) request, Oak Ridge National Laboratory (ORNL) staff prepared report NUREG/CR7109, An Approach for Validating Actinide and Fission Product Burnup Credit Criticality Safety Analyses-Criticality ( $\left.k_{\text {eff }}\right)$ Predictions (Ref. 1), which included recommendations for addressing validation of fission products and minor actinides (FP\&MA) in $k_{\text {eff }}$ calculations. Based in part on the uncertainty analysis work presented in NUREG/CR-7109, the NRC Division of Spent Fuel Management provided the following guidance in Recommendation 4 of Interim Staff Guidance (ISG) 8, Rev. 3 (Ref. 2) (some supplementary explanation is provided within brackets in the following text):

"Fission product and minor actinide credit

The applicant may credit the minor actinide and fission product nuclides listed in Table 2 [of ISG-8, Rev. 3; Table 2 lists the FP\&MA shown in Table 1.1 in this report], provided the bias and bias uncertainty associated with the major actinides is determined as 
described above [ISG-8, Rev. 3 provides guidance for validation of major actinides]. One point five percent $(1.5 \%)$ of the worth of the minor actinides and fission products conservatively covers the bias due to these isotopes. Due to the conservatism in this value, no additional uncertainty in the bias needs to be applied. This estimate is appropriate provided the applicant:

- uses the SCALE code system with the ENDF/B-V [Evaluated Nuclear Data Files, Part B-V], ENDF/B-VI, or ENDF/B-VII cross section libraries,

- can justify that its design is similar to the hypothetical GBC-32 [generic burnup credit cask-32] system design used as the basis for the NUREG/CR-7109 criticality validation, and

- demonstrates that the credited minor actinide and fission product worth is no greater than 0.1 in keff.

For well qualified, industry standard code systems other than SCALE with the ENDF/B-V, ENDF/B-VI, or ENDF/B-VII cross section libraries, a conservative estimate for the bias associated with minor actinide and fission product nuclides of $3.0 \%$ of their worth may be used. Use of a minor actinide and fission product bias less than $3.0 \%$ should be accompanied by additional justification that the lower value is an appropriate estimate of the bias associated with that code system."

The FP\&MA nuclides covered by the guidance are listed in Table 2 of ISG-8, Rev. 3, and below in Table 1.1.

Table 1.1. Fission products and minor actinides

\begin{tabular}{|cccc|}
\hline \multicolumn{4}{|c|}{ Fission products } \\
\hline${ }^{95} \mathrm{Mo}$ & ${ }^{99} \mathrm{Tc}$ & ${ }^{101} \mathrm{Ru}$ & ${ }^{103} \mathrm{Rh}$ \\
${ }^{109} \mathrm{Ag}$ & ${ }^{133} \mathrm{Cs}$ & ${ }^{143} \mathrm{Nd}$ & ${ }^{145} \mathrm{Nd}$ \\
${ }^{147} \mathrm{Sm}$ & ${ }^{149} \mathrm{Sm}$ & ${ }^{150} \mathrm{Sm}$ & ${ }^{151} \mathrm{Sm}$ \\
${ }^{152} \mathrm{Sm}$ & ${ }^{151} \mathrm{Eu}$ & ${ }^{153} \mathrm{Eu}$ & ${ }^{155} \mathrm{Gd}$ \\
\hline \multicolumn{4}{|c|}{ Minor actinides } \\
\hline
\end{tabular}

This report provides a complete description of a GBC-32 model loaded with pressurized water reactor (PWR) SNF. Single-axial zone burned fuel compositions are provided at fuel burnups of 20 and $40 \mathrm{GWd} / \mathrm{MTU}$ for post-irradiation cooling times of 5 and 40 years. Reference FP\&MA worths are provided for the four burnup and cooling time combinations for several of the nuclear data libraries available in SCALE 6.1 (Ref. 3). Comparisons of SCALE 6.1 and Monte Carlo $\mathrm{N}$-Particle (MCNP) (Ref. 4) FP\&MA worths are also provided.

Since the FP\&MA worths calculated using MCNP are either lower than or statistically the same as the SCALE results (see Table 4.1), these comparisons demonstrate that it is appropriate to apply the $1.5 \%$ of the FP\&MA worth bias to MCNP calculations using ENDF/B-V, -VI, -VII and - VII.1 data. This additional bias term supplements the MCNP $k_{\text {eff }}$ calculation validation, thereby addressing the lack of $\mathrm{k}_{\text {eff }}$ validation for the FP\&MAs. 


\subsection{CALCULATION METHOD}

The calculation method described in this section demonstrates that MCNP used with its ENDF/B-V, $-\mathrm{VI},-\mathrm{VII}$ or $-\mathrm{VII} .1$ based data sets produces FP\&MA worth results that are similar to results generated using the SCALE 6.1 code system with ENDF/B-V, $-\mathrm{VI}$ and $-\mathrm{VII}$ based nuclear data libraries.

The calculation method used is the following:

1. SCALE Criticality Safety Analysis Sequence-5 (CSAS5) and MCNP criticality calculations are performed for the GBC-32 cask (Ref. 5) loaded with burned PWR fuel at 20 and $40 \mathrm{GWd} / \mathrm{MTU}$ burnups and with post-irradiation cooling times of 5 and 40 years. Complete descriptions of the cask and fuel assembly geometry and materials are provided in Section 2. Single axial zone burned fuel compositions are provided at burnup values of 20 and $40 \mathrm{GWd} / \mathrm{MTU}$ for 5 - and 40 -year post-irradiation cooling times. SCALE CSAS5 and MCNP cask models and code-specific (i.e., in code-specific input format) burned fuel composition inputs are provided in Appendixes A and B of this report.

To simplify the calculations, single axial zone models are used for the determination of FP\&MA worth. This is done because the goal is to show that given the same models and compositions, the MCNP FP\&MA worths will be similar to the FP\&MA worths calculated using SCALE. Comparisons are made at 20 and $40 \mathrm{GWd} / \mathrm{MTU}$ burnups following 5- and 40-year post-irradiation cooling times to demonstrate that the comparison is valid over a range of safety analysis model parameters.

2. Results from criticality calculations performed with and without the FP\&MAs are used to calculate the FP\&MA worth for each burnup and cooling time combination. The FP\&MA worths are calculated by subtracting the $k_{\text {eff }}$ calculated with FP\&MA removed from the $k_{\text {eff }}$ calculated with all FP\&MAs present.

3. The calculated FP\&MA worth results are then compared to FP\&MA reference results presented in Table 3.1 in Section 3. The reference results were calculated, consistent with the computational method used to generate NUREG/CR-7109, using SCALE 6.1 and its ENDF/B-VII 238 energy group library. Detailed nuclide-by-nuclide $k_{\text {eff }}$ worth results for other nuclear data libraries and for MCNP are provided in Appendix C.

Under prediction of FP\&MA worth leads to the calculation of a smaller FP\&MA bias term, but the reduced FP\&MA worth has a significantly larger and more conservative impact on the maximum $k_{\text {eff }}$ through the calculated $k_{\text {eff }}$ value than does the reduction in the uncertainty associated with the $1.5 \%$ of FP\&MA worth bias term. Consequently, variation of FP\&MA worth below the reference FP\&MA reference values is reasonable because the calculated FP\&MA worths do not exceed the reference results FP\&MA worths by more than $1.5 \%$.

Subject to additional considerations prescribed by ISG-8, Rev. 3 and described earlier in this section, it is recommended that the $1.5 \%$ of the FP\&MA worth uncertainty be used in MCNP based $k_{\text {eff }}$ analyses to cover the poor validation of FP\&MA nuclides in MCNP $k_{\text {eff }}$ calculations. 



\section{REFERENCE MODEL DESCRIPTION}

The following subsections describe the reference model used to generate the FP\&MA worths presented in Sections 3 and 4 and in Appendix C. The cask and SNF model used is the same as is described in NUREG/CR-6747 (Ref. 5). For the reader's convenience, relevant model information is provided in Sections 2.1 and 2.2. The burned PWR fuel compositions used in the reference model are described in Section 2.3. Input listings for the SCALE 6.1 CSAS5 and MCNP models of the GBC-32 cask are provided in Appendixes A and B, respectively.

\subsection{GBC-32 CASK MODEL}

As is discussed in NUREG/CR-6747, the GBC-32 cask model was developed as a computational benchmark that could be used for the estimation of the additional reactivity associated with FP\&MA. The model was intended to capture the important features of transport and storage casks without use of non-essential details or proprietary information associated with actual cask designs. The cask holds 32 PWR assemblies in storage cells with $0.75-\mathrm{cm}$-thick steel walls as well as one Boral ${ }^{\mathrm{TM}}$ plate between each pair of assemblies and on the external faces of the basket.

The water-filled cask dimensions and materials are described in Tables Table 2.1 and Table 2.2. Figures Figure 2.1, Figure 2.2, and Figure 2.3 show features of the GBC-32 cask model. Tables Table 2.1 and Table 2.2, and Figures 2.1 and Figure 2.2 were reproduced from NUREG/CR-6747.

In addition to the information provided in Tables 2.1 and Table 2.2, the Boral ${ }^{\mathrm{TM}}$ panel present on the outside of each external fuel assembly storage cell is covered by a 0.75 -cm-thick type 304 stainless steel plate. The width of each external vertical steel plate shown in Figure 2.1 matches the storage cell inside dimension of $22.0 \mathrm{~cm}$. The width of each external horizontal steel plate matches the storage cell outside dimension of $23.5 \mathrm{~cm}$. 
Table 2.1. Physical dimensions for the GBC-32 cask

\begin{tabular}{|c|c|c|}
\hline Parameter & Inches & Centimeters \\
\hline Cell inside dimension & 8.6614 & 22.0000 \\
\hline Cell outside dimension & 9.2520 & 23.5000 \\
\hline Cell wall thickness & 0.2953 & 0.7500 \\
\hline Boral $^{\mathrm{TM}}$ panel thickness ${ }^{a}$ & 0.1010 & 0.2565 \\
\hline Boral $^{\mathrm{TM}}$ center thickness & 0.0810 & 0.2057 \\
\hline Boral $^{\mathrm{TM}}$ Al plate thickness & 0.0100 & 0.0254 \\
\hline Cell pitch & 9.3530 & 23.7565 \\
\hline Boral panel width & 7.5000 & 19.0500 \\
\hline Cell height $^{b}$ & 144.0000 & 365.76 \\
\hline Boral $^{\mathrm{TM}}$ panel height ${ }^{b}$ & 144.0000 & 365.76 \\
\hline Cask inside diameter & 68.8976 & 175.0000 \\
\hline Cask outside diameter & 84.6457 & 215.0000 \\
\hline Cask radial thickness & 7.8740 & 20.0000 \\
\hline Base plate thickness & 11.8110 & 30.0000 \\
\hline Cask lid thickness & 11.8110 & 30.0000 \\
\hline Cask inside height & 161.7165 & 410.7600 \\
\hline Active fuel height ${ }^{b}$ & 144.0000 & 365.76 \\
\hline Bottom assembly hardware thickness & 5.9055 & 15.0000 \\
\hline Top assembly hardware thickness & 11.8110 & 30.0000 \\
\hline
\end{tabular}

${ }^{a}$ Boral $^{\mathrm{TM}}$ is a clad composite of aluminum and boron carbide. A Boral ${ }^{\mathrm{TM}}$ panel or plate consists of three distinct layers. The outer layers are aluminum cladding, which form a sandwich with a central layer that consists of a uniform aggregate of fine boron carbide particles within an aluminum alloy matrix.

${ }^{b}$ The cell height, Boral ${ }^{\mathrm{TM}}$ panel height, and active fuel height are all equivalent, and their lower boundaries are coincident, $15 \mathrm{~cm}$ above the base plate. 
Table 2.2. Material compositions for GBC-32 cask model

\begin{tabular}{|c|c|c|}
\hline Isotope & $\begin{array}{c}\text { Atom density } \\
\text { (atoms/barn-cm) }\end{array}$ & Weight percent \\
\hline \multicolumn{3}{|c|}{ Water (density $=0.9983 \mathrm{~g} / \mathrm{cm}^{3}$ ) } \\
\hline Hydrogen $(\mathrm{H})$ & 0.06674 & 11.19 \\
\hline Oxygen (O) & 0.03337 & 88.81 \\
\hline Total & 0.10011 & 100.0 \\
\hline \multicolumn{3}{|c|}{ Stainless steel $304\left(\right.$ density $\left.=7.92 \mathrm{~g} / \mathrm{cm}^{3}\right)($ Ref. 6) } \\
\hline Chromium (Cr) & 0.01743 & 19.0 \\
\hline Manganese (Mn) & 0.00174 & 2.0 \\
\hline Iron $(\mathrm{Fe})$ & 0.05936 & 69.5 \\
\hline Nickel (Ni) & 0.00772 & 9.5 \\
\hline Total & 0.08625 & 100.0 \\
\hline \multicolumn{3}{|c|}{ Boral $^{\mathrm{TM}}$ panel aluminum cladding (density $=2.699 \mathrm{~g} / \mathrm{cm}^{3}$ ) } \\
\hline Aluminum (Al) & 0.0602 (Ref. 7) & 100.0 \\
\hline Total & 0.0602 & 100.0 \\
\hline \multicolumn{3}{|c|}{ Boral $^{\mathrm{TM}}$ panel central layer $\left(0.0225 \mathrm{~g}^{10} \mathrm{~B} / \mathrm{cm}^{2}\right)^{a}$} \\
\hline Boron-10 $\left({ }^{10} \mathrm{~B}\right)$ & $6.5794 \mathrm{E}-03$ & 4.13 \\
\hline Boron-11 $\left({ }^{11} \mathrm{~B}\right)$ & $2.7260 \mathrm{E}-02$ & 18.81 \\
\hline Carbon (C) & 8.4547E-03 & 6.37 \\
\hline Aluminum (Al) & 4.1795E-02 & 70.69 \\
\hline Total & 8.4089E-02 & 100.0 \\
\hline
\end{tabular}

${ }^{a}$ Note: $0.030 \mathrm{~g}^{10} \mathrm{~B} / \mathrm{cm}^{2}$ is the loading from the manufacturer $\left(\mathrm{AAR}^{8}\right)$ that corresponds to the modeled Boral panel thickness of 0.101 inches. However, current NRC guidance ${ }^{9}$ recommends only $75 \%$ credit for fixed neutron absorbers, and thus $75 \%$ of 0.030 , or $0.0225 \mathrm{~g}$ ${ }^{10} \mathrm{~B} / \mathrm{cm}^{2}$ is used. 


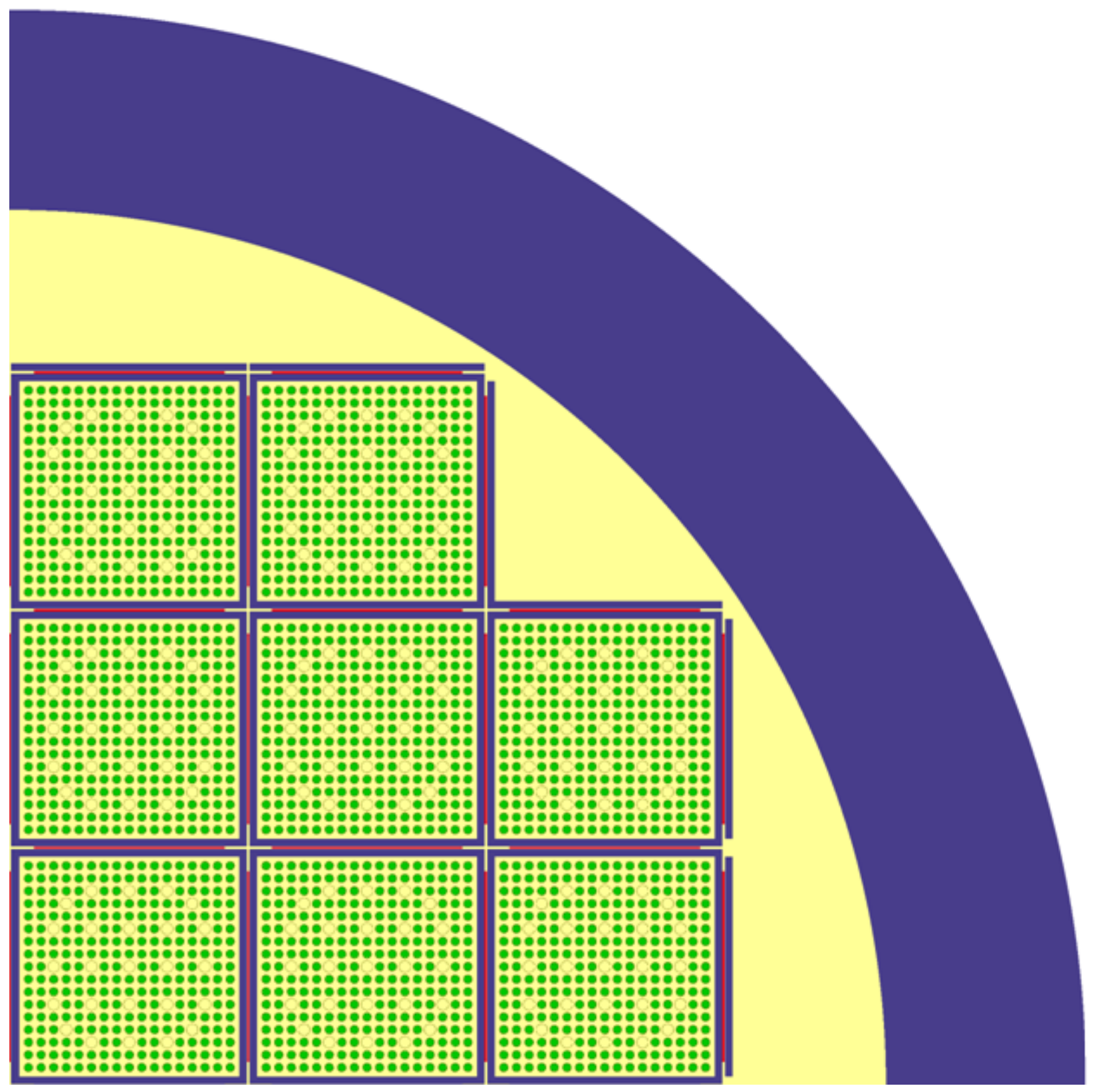

Figure 2.1. Radial cross section of one-quarter of the GBC-32 cask 


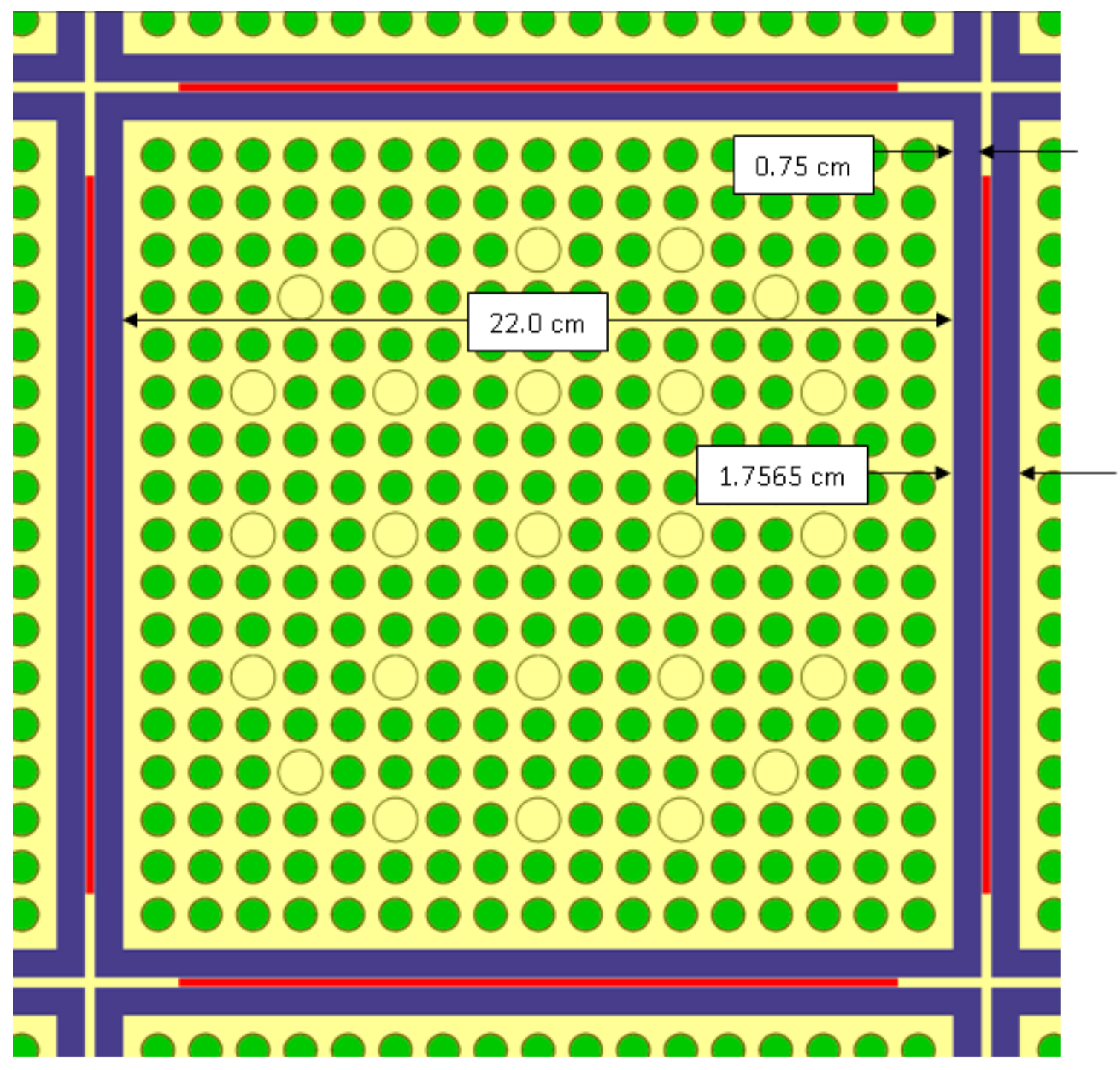

Figure 2.2. Cross-sectional view of an assembly cell in KENO V.a model for the GBC-32 cask 


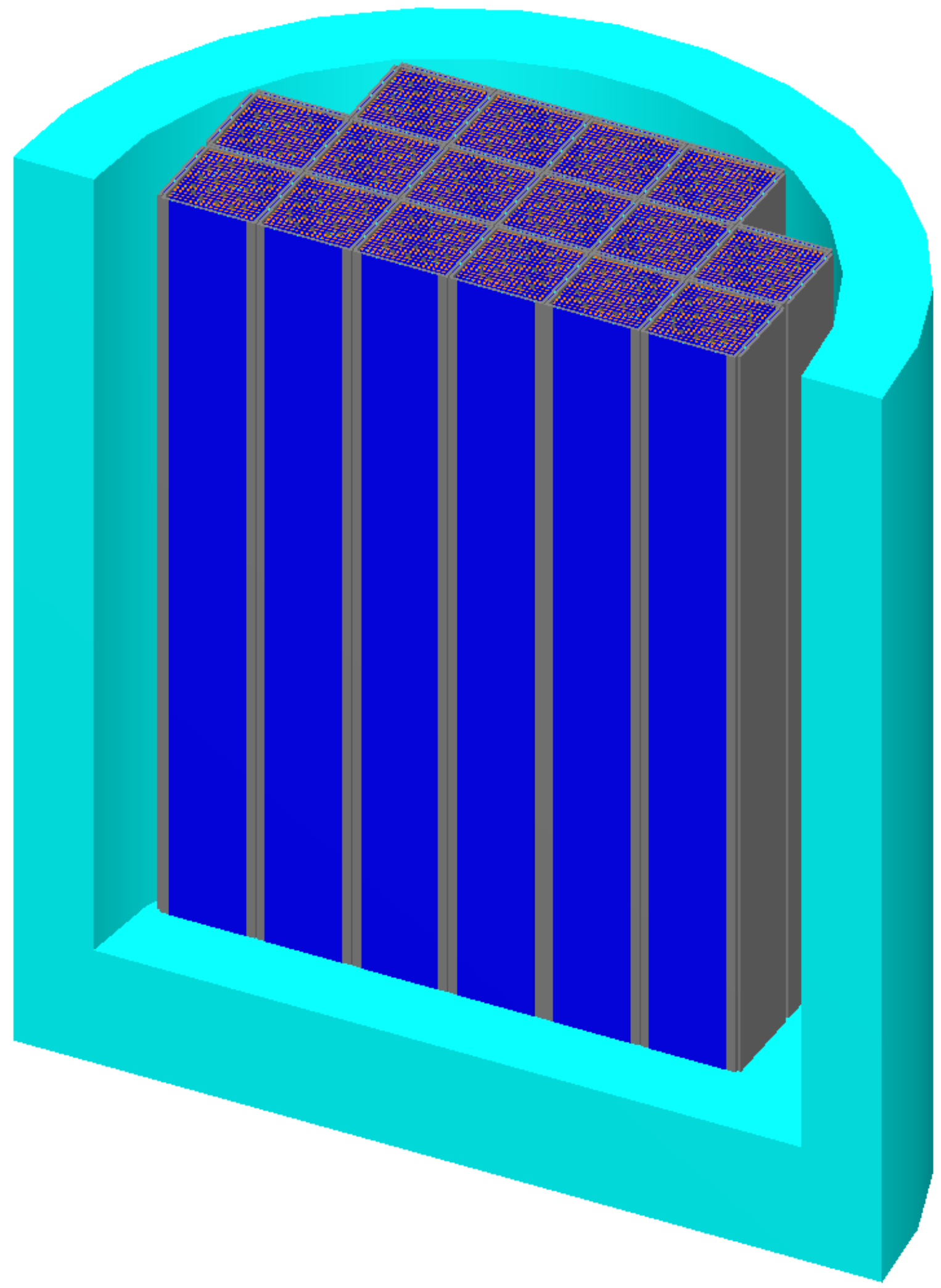

Figure 2.3. Isometric view of GBC-32 cask with top and front halves removed 


\subsection{PWR FUEL ASSEMBLY SPECIFICATION}

The reference PWR fuel assembly design used in NUREG/CR-6747 and in NUREG/CR-7109 is representative of a Westinghouse $17 \times 17$ Optimized Fuel Assembly (OFA). To be consistent with prior work, the same assembly design is used in this report for calculation of the reference FP\&MA worths. The simplified model used here and in NUREG/CR-6747 replaces the assembly grids and assembly structures above and below the active fuel length with water. Thus the simplified fuel assembly model is a 365.76 -cm-long $17 \times 17$ array of fuel pins and guide tubes. Table 2.3, reproduced here from Table 3 of NUREG/CR-6747, provides the fuel assembly specifications.

The spent fuel pellet compositions will be addressed in the next section. The fuel rod clad, guide tubes, and instrument tube are all modeled as $100 \%$ zirconium, having an atom density of 0.0423 atoms per barn-cm (Ref. Error! Bookmark not defined.).

Table 2.3. PWR fuel assembly specifications

\begin{tabular}{|l|c|c|}
\hline \multicolumn{1}{|c|}{ Parameter } & Inches & Centimeters \\
\hline Fuel outside diameter & 0.3088 & 0.7844 \\
\hline Cladding inside diameter & 0.3150 & 0.8001 \\
\hline Cladding outside diameter & 0.3600 & 0.9144 \\
\hline Cladding radial thickness & 0.0225 & 0.0572 \\
\hline Rod pitch & 0.4960 & 1.2598 \\
\hline Guide tube/thimble inside diameter & 0.4420 & 1.1227 \\
\hline Guide tube/thimble outside diameter & 0.4740 & 1.2040 \\
\hline Thimble radial thickness & 0.0160 & 0.0406 \\
\hline Instrument tube inside diameter & 0.4420 & 1.1227 \\
\hline Instrument tube outside diameter & 0.4740 & 1.2040 \\
\hline Instrument tube radial thickness & 0.0160 & 0.0406 \\
\hline Active fuel length & 144 & 365.76 \\
\hline \hline Array size & \multicolumn{2}{|c|}{$17 \times 17$} \\
\hline Number of fuel rods & \multicolumn{2}{|c|}{1} \\
\hline Number of guide tubes/thimbles & \multicolumn{2}{|c|}{} \\
\hline Number of instrument tubes & \multicolumn{2}{|c|}{} \\
\hline
\end{tabular}

\subsection{REFERENCE MODEL FUEL COMPOSITIONS}

For the purposes of the reference FP\&MA worth calculations, fuel compositions were calculated for two initial enrichment/final burnup pairs along a representative loading curve determined for the analysis documented in NUREG/CR-7109 (Ref. 1). This loading curve is the "Actinides \& 16 FP" loading curve shown below in Figure 2.4, which was reproduced from Figure 4.4 of NUREG/CR-7109. The models used to generate the loading curves shown in the figure included 
an 18-axial zone burnup distribution and a 5-year post-irradiation cooling time. The background in this figure shows all PWR fuel inventory as of the end of 2002 according to the RW-859 (2002) data (Ref. 10).

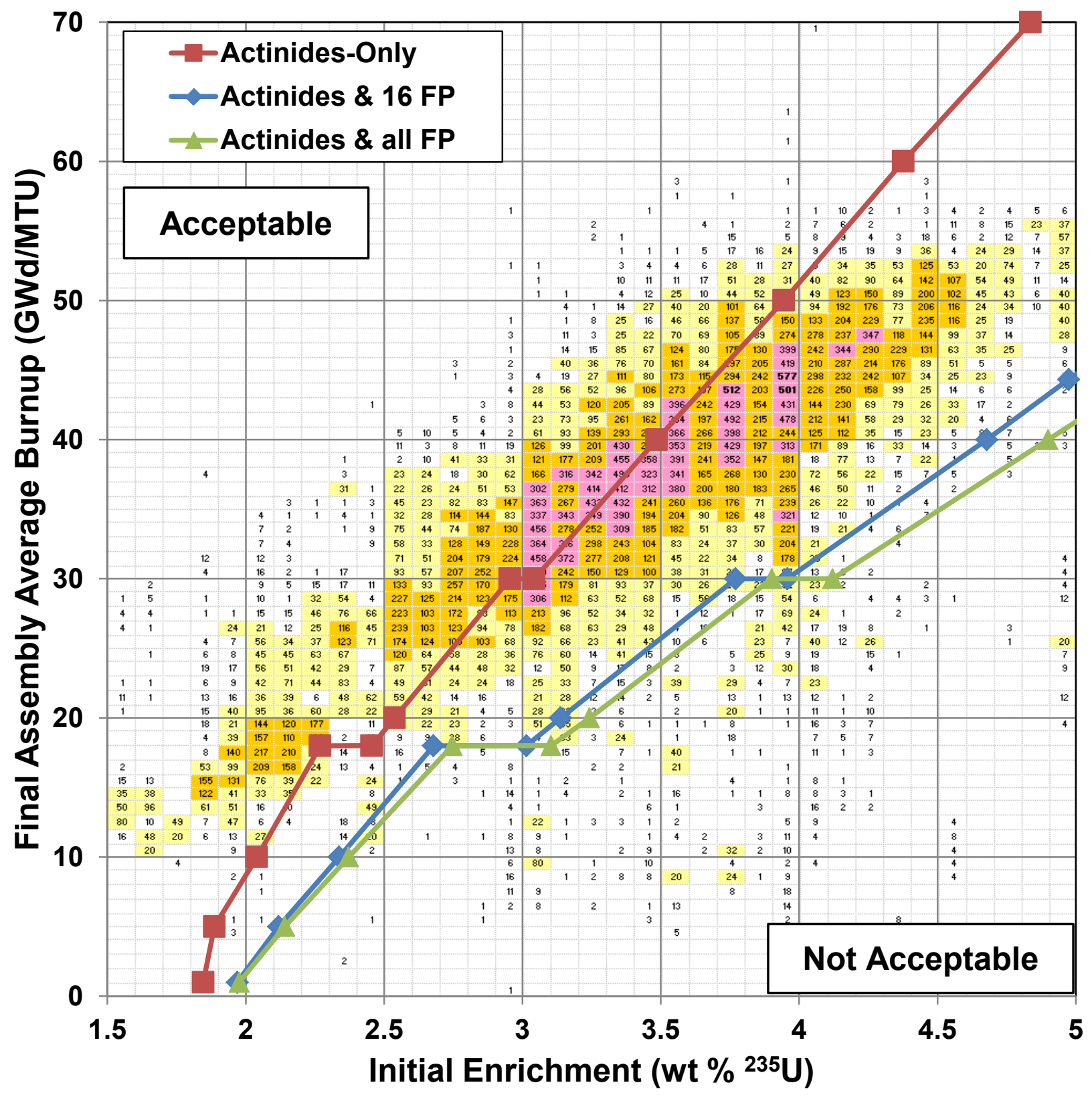

Figure 2.4. Burnup credit loading curves for the GBC-32 application models

In particular, the fuel compositions used in the reference FP\&MA worth calculations are for fuel with initial enrichments of 3.14 and 4.68 wt $\%{ }^{235} \mathrm{U}$ burned to 20 and $40 \mathrm{GWd} / \mathrm{MTU}$, respectively. Fuel compositions were generated for each combination with both a 5-year and 40-year postirradiation cooling time. Table 2.4 provides the burned fuel compositions used in the calculation of the reference FP\&MA worth values. These irradiated fuel compositions were generated using the same computational methods described in NUREG/CR-7109 (Ref. 1). 
Table 2.4. Burned fuel compositions for reference FP\&MA worth calculations

\begin{tabular}{|c|c|c|c|c|c|}
\hline & \multirow{2}{*}{$\begin{array}{c}\begin{array}{c}\text { Initial } \\
\text { enrichment } \\
\text { and } \\
\text { final burnup }\end{array} \\
\text { Cooling time }\end{array}$} & \multicolumn{2}{|c|}{$3.1 \mathrm{wt} \%$ and $20 \mathrm{GWd} / \mathrm{MTU}$} & \multicolumn{2}{|c|}{$4.7 \mathrm{wt} \%$ and $40 \mathrm{GWd} / \mathrm{MTU}$} \\
\hline & & 5 years & 40 years & 5 years & 40 years \\
\hline & Nuclide & & $\begin{array}{l}\text { Atom } \\
\text { (atom }\end{array}$ & $\begin{array}{l}\text { sities } \\
\text { (n-cm) }\end{array}$ & \\
\hline \multirow{9}{*}{ 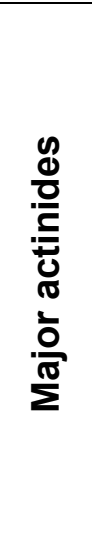 } & ${ }^{234} \mathrm{U}$ & $7.3901 \mathrm{E}-08$ & $3.2108 \mathrm{E}-07$ & $2.6245 \mathrm{E}-07$ & $1.3559 \mathrm{E}-06$ \\
\hline & ${ }^{235} \mathrm{U}$ & 3.6046E-04 & $3.6060 \mathrm{E}-04$ & 3.6741E-04 & 3.6758E-04 \\
\hline & ${ }^{238} \mathrm{U}$ & $2.2345 \mathrm{E}-02$ & $2.2345 \mathrm{E}-02$ & 2.1683E-02 & $2.1683 \mathrm{E}-02$ \\
\hline & ${ }^{238} \mathrm{Pu}$ & 1.0223E-06 & 7.7547E-07 & $4.5238 \mathrm{E}-06$ & $3.4316 \mathrm{E}-06$ \\
\hline & ${ }^{239} \mathrm{Pu}$ & 1.3719E-04 & $1.3705 \mathrm{E}-04$ & 1.7413E-04 & $1.7396 \mathrm{E}-04$ \\
\hline & ${ }^{240} \mathrm{Pu}$ & 3.9569E-05 & 3.9477E-05 & $6.3031 \mathrm{E}-05$ & $6.3301 \mathrm{E}-05$ \\
\hline & ${ }^{241} \mathrm{Pu}$ & $1.6819 \mathrm{E}-05$ & 3.0797E-06 & 3.2475E-05 & 5.9464E-06 \\
\hline & ${ }^{242} \mathrm{Pu}$ & 3.8879E-06 & 3.8877E-06 & $1.1666 \mathrm{E}-05$ & 1.1665E-05 \\
\hline & ${ }^{241} \mathrm{Am}$ & 4.8440E-06 & $1.7840 \mathrm{E}-05$ & $9.7110 \mathrm{E}-06$ & $3.4784 \mathrm{E}-05$ \\
\hline \multirow{3}{*}{$\frac{\stackrel{0}{0}}{\frac{0}{0}}$} & ${ }^{236} \mathrm{U}$ & 7.0106E-05 & $7.0252 \mathrm{E}-05$ & $1.3508 \mathrm{E}-04$ & $1.3532 \mathrm{E}-04$ \\
\hline & ${ }^{237} \mathrm{~Np}$ & $5.5048 \mathrm{E}-06$ & $6.2485 \mathrm{E}-06$ & 1.3907E-05 & $1.5362 \mathrm{E}-05$ \\
\hline & ${ }^{243} \mathrm{Am}$ & $5.1541 \mathrm{E}-07$ & $5.1371 \mathrm{E}-07$ & $2.5940 \mathrm{E}-06$ & 2.5854E-06 \\
\hline \multirow{18}{*}{$\begin{array}{l}\frac{n}{U} \\
\frac{D}{0} \\
\frac{0}{2} \\
\frac{0}{0} \\
\frac{0}{n} \\
\frac{0}{4}\end{array}$} & ${ }^{95} \mathrm{Mo}$ & $2.8435 \mathrm{E}-05$ & $2.8435 \mathrm{E}-05$ & 5.4717E-05 & 5.4717E-05 \\
\hline & ${ }^{99} \mathrm{Tc}$ & $2.9026 \mathrm{E}-05$ & $2.9023 \mathrm{E}-05$ & $5.5148 \mathrm{E}-05$ & $5.5142 \mathrm{E}-05$ \\
\hline & ${ }^{101} \mathrm{Ru}$ & 2.6347E-05 & 2.6347E-05 & $5.1618 \mathrm{E}-05$ & $5.1618 \mathrm{E}-05$ \\
\hline & ${ }^{103} \mathrm{Rh}$ & $1.8264 \mathrm{E}-05$ & $1.8264 \mathrm{E}-05$ & 3.1900E-05 & $3.1900 \mathrm{E}-05$ \\
\hline & ${ }^{109} \mathrm{Ag}$ & 2.1375E-06 & $2.1375 \mathrm{E}-06$ & 4.3961E-06 & 4.3961E-06 \\
\hline & ${ }^{133} \mathrm{Cs}$ & 3.0552E-05 & 3.0552E-05 & 5.7163E-05 & 5.7163E-05 \\
\hline & ${ }^{143} \mathrm{Nd}$ & $2.2819 \mathrm{E}-05$ & $2.2819 \mathrm{E}-05$ & 4.1309E-05 & 4.1309E-05 \\
\hline & ${ }^{145} \mathrm{Nd}$ & 1.6695E-05 & $1.6695 \mathrm{E}-05$ & 3.1395E-05 & $3.1395 \mathrm{E}-05$ \\
\hline & ${ }^{147} \mathrm{Sm}$ & 5.6742E-06 & 7.4723E-06 & 9.3467E-06 & $1.1950 \mathrm{E}-05$ \\
\hline & ${ }^{149} \mathrm{Sm}$ & $1.7982 \mathrm{E}-07$ & $1.7982 \mathrm{E}-07$ & $2.2875 \mathrm{E}-07$ & $2.2875 \mathrm{E}-07$ \\
\hline & ${ }^{150} \mathrm{Sm}$ & $6.4540 \mathrm{E}-06$ & $6.4540 \mathrm{E}-06$ & 1.3517E-05 & $1.3517 \mathrm{E}-05$ \\
\hline & ${ }^{151} \mathrm{Sm}$ & 4.1578E-07 & 3.1754E-07 & $6.4777 \mathrm{E}-07$ & 4.9471E-07 \\
\hline & ${ }^{152} \mathrm{Sm}$ & 2.6638E-06 & $2.6639 \mathrm{E}-06$ & $4.2868 \mathrm{E}-06$ & $4.2871 \mathrm{E}-06$ \\
\hline & ${ }^{151} \mathrm{Eu}$ & $1.6613 \mathrm{E}-08$ & 1.1485E-07 & 2.5993E-08 & $1.7905 \mathrm{E}-07$ \\
\hline & ${ }^{153} \mathrm{Eu}$ & $2.2518 \mathrm{E}-06$ & $2.2518 \mathrm{E}-06$ & 4.9812E-06 & 4.9812E-06 \\
\hline & ${ }^{155} \mathrm{Gd}$ & $7.0661 \mathrm{E}-08$ & $1.3548 \mathrm{E}-07$ & $1.7686 \mathrm{E}-07$ & $3.3841 \mathrm{E}-07$ \\
\hline & ${ }^{16} \mathrm{O}$ & 4.6943E-02 & 4.6943E-02 & 4.6949E-02 & 4.6949E-02 \\
\hline & Total & $7.0120 \mathrm{E}-02$ & 7.0122E-02 & $6.9808 \mathrm{E}-02$ & $6.9811 \mathrm{E}-02$ \\
\hline
\end{tabular}


As has been shown in prior work (Ref. 11), accurate $k_{\text {eff }}$ determination for PWR spent fuel systems requires that the axial burnup distribution be modeled. The calculations performed for this report used a single axially uniform fuel composition for each burnup and post-irradiation cooling time. This was done to simplify the calculations and is appropriate because the objective of the calculations is limited to showing that the other computational methods (e.g., MCNP with ENDF/B-V, -VI, -VII, and -VII.1 nuclear data) generate FP\&MA worth results that are similar to the reference results. Calculations and comparisons were made at two burnup/enrichment points and for two post-irradiation cooling times to demonstrate that the comparisons made and conclusions reached are valid over the range of burned fuel compositions typically observed in burnup credit criticality analyses for transportation and dry storage operations. 


\section{REFERENCE FP\&MA WORTHS}

The nuclear data uncertainty analysis results, which were presented in NUREG/CR-7109 and served as the basis for ISG-8, Rev. 3, Recommendation 4, were generated using the SCALE 6.1 CSAS5 sequence and the ENDF/B-VII-based 238 neutron energy group library (v7-238). In that work, the CSAS5 sequence used the CENTRM module to perform resolved resonance calculations and performed KENO V.a Monte Carlo method neutron transport calculations.

The same computational method was used to generate the reference FP\&MA worth results, which are presented in Table 3.1. The models described in Section 2, including the burned fuel composition information provided in Table 2.4, were used to calculate the reference FP\&MA worths. Nominal calculations were performed with all of the nuclides present. Individual calculations were also performed with each of the FP and MA removed, with all FP\&MA removed, with all MA removed, and with all FP removed. The group or individual nuclide worth values were then calculated as the change in $k_{\text {eff }}$ because of the presence of the nuclide or group of nuclides using the following equation:

worth $_{\text {nuclide or group }}=\mathrm{k}_{\text {nominal }}-\mathrm{k}_{\text {nuclide or group removed }}$

The results presented in the "All FP\&MA," "All MA," and "All FP" rows of Table 3.1 were calculated with the group constituents simultaneously removed. The reference FP\&MA worth results to be used for comparison with results from other computational methods are the worths listed in the "All FP\&MA" row. The other worth values are provided for reference and to facilitate more detailed comparisons. 
Table 3.1. Reference FP\&MA worth results using SCALE 6.1 and the ENDF/B-VII 238 group nuclear data library

\begin{tabular}{|c|c|c|c|c|}
\hline \multirow{2}{*}{$\begin{array}{c}\text { Initial enrichment and } \\
\text { final burnup } \\
\begin{array}{c}\text { Cooling time } \\
\text { (years) }\end{array}\end{array}$} & \multicolumn{2}{|c|}{$3.1 \mathrm{wt} \%$ and $20 \mathrm{GWd} / \mathrm{MTU}$} & \multicolumn{2}{|c|}{4.7 wt $\%$ and $40 \mathrm{GWd} / \mathrm{MTU}$} \\
\hline & 5 & 40 & 5 & 40 \\
\hline & \multicolumn{4}{|c|}{$\begin{array}{l}\text { Reactivity worth values } \\
\qquad(\Delta k)^{a}\end{array}$} \\
\hline $\begin{array}{c}\text { All FP\&MA } \\
\text { (reference worth) }\end{array}$ & -0.06742 & -0.06921 & -0.10203 & -0.10442 \\
\hline All MA & -0.00602 & -0.00588 & -0.01154 & -0.01093 \\
\hline All FP & -0.06058 & -0.06206 & -0.08820 & -0.09085 \\
\hline${ }^{236} U$ & -0.00373 & -0.00359 & -0.00579 & -0.00526 \\
\hline${ }^{237} \mathrm{~Np}$ & -0.00193 & -0.00210 & -0.00488 & -0.00459 \\
\hline${ }^{243} \mathrm{Am}$ & -0.00022 & -0.00020 & -0.00128 & -0.00108 \\
\hline${ }^{95} \mathrm{Mo}$ & -0.00123 & -0.00078 & -0.00207 & -0.00158 \\
\hline${ }^{99} \mathrm{Tc}$ & -0.00278 & -0.00254 & -0.00439 & -0.00370 \\
\hline${ }^{101} \mathrm{Ru}$ & -0.00088 & -0.00072 & -0.00165 & -0.00155 \\
\hline${ }^{103} \mathrm{Rh}$ & -0.00681 & -0.00616 & -0.01023 & -0.00934 \\
\hline${ }^{109} \mathrm{Ag}$ & -0.00105 & -0.00058 & -0.00180 & -0.00154 \\
\hline${ }^{133} \mathrm{Cs}$ & -0.00324 & -0.00309 & -0.00551 & -0.00490 \\
\hline${ }^{143} \mathrm{Nd}$ & -0.00895 & -0.00864 & -0.01348 & -0.01269 \\
\hline${ }^{145} \mathrm{Nd}$ & -0.00187 & -0.00163 & -0.00332 & -0.00279 \\
\hline${ }^{147} \mathrm{Sm}$ & -0.00139 & -0.00157 & -0.00223 & -0.00241 \\
\hline${ }^{149} \mathrm{Sm}$ & -0.01570 & -0.01502 & -0.01646 & -0.01541 \\
\hline${ }^{150} \mathrm{Sm}$ & -0.00095 & -0.00092 & -0.00165 & -0.00159 \\
\hline${ }^{151} \mathrm{Sm}$ & -0.00588 & -0.00440 & -0.00760 & -0.00562 \\
\hline${ }^{152} \mathrm{Sm}$ & -0.00233 & -0.00199 & -0.00323 & -0.00286 \\
\hline${ }^{151} \mathrm{Eu}$ & -0.00027 & -0.00107 & -0.00043 & -0.00157 \\
\hline${ }^{153} \mathrm{Eu}$ & -0.00150 & -0.00133 & -0.00309 & -0.00260 \\
\hline${ }^{155} \mathrm{Gd}$ & -0.00359 & -0.00659 & -0.00738 & -0.01330 \\
\hline
\end{tabular}

${ }^{a}$ Monte Carlo uncertainty $(1 \sigma)$ is $0.00014 \Delta k$ and is not included in the FP\&MA worths. 


\section{MCNP RESULTS}

FP\&MA reactivity worth calculations were performed using MCNP5 version 1.60 and MCNP6 with available continuous-energy nuclear data libraries including ENDF/B-V, -VI, -VII and -VII.1. FP\&MA worth results for these data sets and codes are provided in Table 4.1.

Table 4.1. Variation in calculated FP\&MA worths using various codes and data

\begin{tabular}{|c|c|c|c|c|c|}
\hline \multirow{2}{*}{\multicolumn{2}{|c|}{$\begin{array}{c}\text { Initial enrichment and final burnup } \\
\text { Cooling time (years) }\end{array}$}} & \multicolumn{2}{|c|}{$\begin{array}{l}3.1 \text { wt } \% \text { and } 20 \\
\text { GWd/MTU }\end{array}$} & \multicolumn{2}{|c|}{$\begin{array}{l}4.7 \text { wt \% and } 40 \\
\text { GWd/MTU }\end{array}$} \\
\hline & & 5 & 40 & 5 & 40 \\
\hline Code & $\begin{array}{l}\text { Nuclear } \\
\text { data }^{a}\end{array}$ & \multicolumn{4}{|c|}{ FP\&MA worths $(\Delta)^{b}$ and $\%$ change from reference } \\
\hline $\begin{array}{c}\text { SCALE 6.1 (CENTRM) } \\
\text { (reference worth) }\end{array}$ & v7-238 & -0.06742 & -0.06921 & -0.10203 & -0.10442 \\
\hline \multirow{2}{*}{ MCNP5 (1.60) } & ENDF/B-VII & -0.06748 & -0.06969 & -0.10213 & -0.10456 \\
\hline & $(\% \text { change })^{c}$ & +0.1 & +0.7 & +0.1 & +0.1 \\
\hline \multirow{2}{*}{ MCNP6 } & ENDF/B-VII & -0.06762 & -0.06961 & -0.10222 & -0.10450 \\
\hline & $(\% \text { change })^{c}$ & +0.3 & +0.6 & +0.2 & +0.1 \\
\hline \multirow{2}{*}{ MCNP6 } & ENDF/B-VII.1 & -0.06663 & -0.0684 & -0.10099 & -0.10268 \\
\hline & $(\% \text { change })^{c}$ & -1.2 & -1.2 & -1.0 & -1.7 \\
\hline \multirow{2}{*}{ MCNP5 (1.60) } & ENDF/B-V & -0.06688 & -0.06913 & -0.10154 & -0.10402 \\
\hline & $(\% \text { change })^{c}$ & -0.8 & -0.1 & -0.5 & -0.4 \\
\hline \multirow{2}{*}{ MCNP6 } & ENDF/B-V & -0.06705 & -0.06906 & -0.10136 & -0.10395 \\
\hline & $(\% \text { change })^{c}$ & -0.6 & -0.2 & -0.7 & -0.5 \\
\hline $\begin{array}{c}\text { SCALE } 6.1 \text { (CENTRM) } \\
\text { (reference worth) }^{d}\end{array}$ & v6-238 & -0.04518 & -0.04923 & -0.06939 & -0.07535 \\
\hline \multirow{2}{*}{ MCNP5 $(1.60)^{d}$} & ENDF/B-VI & -0.04529 & -0.04918 & -0.0691 & -0.07487 \\
\hline & $(\% \text { change })^{c}$ & +0.2 & -0.1 & -0.4 & -0.6 \\
\hline \multirow{2}{*}{$\mathrm{MCNP}^{d}$} & ENDF/B-VI & -0.04525 & -0.04908 & -0.0692 & -0.07511 \\
\hline & $(\% \text { change })^{c}$ & +0.2 & -0.3 & -0.3 & -0.3 \\
\hline
\end{tabular}

${ }^{a}$ The SCALE nuclear data libraries are described in Section M4 of Ref. Error! Bookmark not defined.. The MCNP nuclear data libraries are described in Ref. 4.

${ }^{b}$ The Monte Carlo one-standard deviation uncertainty associated with all reported FP\&MA worths is no greater than $0.00015 \Delta \mathrm{k}$. This uncertainty is not included in the FP\&MA worths.

${ }^{c}$ Percent change from reference worth.

${ }^{d}$ Compositions excluded ${ }^{95} \mathrm{Mo},{ }^{101} \mathrm{Ru},{ }^{143} \mathrm{Nd},{ }^{145} \mathrm{Nd},{ }^{150} \mathrm{Sm},{ }^{151} \mathrm{Sm}$, and ${ }^{152} \mathrm{Sm}$, for which ENDF/B-VI data were not available in MCNP5 (v1.60) and MCNP6.

The $1.5 \%$ of the FP\&MA worth bias term specified in Recommendation 4 of ISG-8, Rev. 3 was based in general on the work reported in NUREG/CR-7109 (Ref. 1) and more specifically on the work reported in Section 7.4.3 of Ref. 1. In that work, the uncertainty information associated with the nuclear data was combined with the nuclide-, reaction-, and energy-dependent sensitivity of $k_{\text {eff }}$ to nuclear data variation for representative spent fuel pool and burnup credit cask models to generate the uncertainty in $k_{\text {eff }}$ due to the uncertainty in nuclear data. The uncertainties in $k_{\text {eff }}$ due to FP\&MA were then compared to their worths, yielding an estimate that $1.5 \%$ of the 
FP\&MA worth would yield a bounding estimate for the biases associated with the FP\&MAs in the GBC-32 model. Information concerning the analysis technique and supporting the determination of the $1.5 \%$ value is presented in NUREG/CR-7109.

Without exception, the results obtained using MCNP vary from the reference values by less than $1.7 \%$ of the FP\&MA worth value. This is expected because the variation between the results is solely due to nuclear data variation or differences in the implementation of the Monte Carlo calculation in SCALE CSAS5 versus MCNP.

Under prediction of FP\&MA worth leads to the calculation of a smaller FP\&MA bias term, but the reduced FP\&MA worth has a significantly larger and more conservative impact on the maximum $k_{\text {eff }}$ through the calculated $k_{\text {eff }}$ value than does the reduction in the $1.5 \%$ of FP\&MA worth bias term. Consequently, variation from the reference values is tolerable, provided the calculated FP\&MA worths do not exceed the reference results by more than $1.5 \%$ of the FP\&MA worths.

These results support the use the $1.5 \%$ of FP\&MA worth bias term described in ISG-8, Rev. 3 , Recommendation 4, when MCNP and the nuclear data sets described in Table 4.1 are used in safety analyses. It may be possible to use the same method and comparisons to justify application of the $1.5 \%$ or $3.0 \%$ of FP\&MA worth biases to results generated using other codes and/or nuclear data.

Some of the reference worths provided in Table 4.1 appear to exceed the restriction provided in Recommendation 4 of ISG-8, Rev. 3, that the credited minor actinide and fission product worth not exceed $0.1 \Delta k_{\text {eff }}$ Some of the FP\&MA worths reported in this work are higher than those reported in NUREG/CR-7109 because of the use of the single-axial zone model, which amplifies the importance of the higher levels of FP\&MAs in the center of the fuel. Further, when the number of significant figures is considered, the $0.10442 \Delta k_{\text {eff }}$ value does not exceed 0.1 . Thus, if the credited FP\&MA worth is slightly higher than $0.1 \Delta k_{\text {eff, }}$ the credited worth should be considered to be no greater than $0.1 \Delta k_{\text {eff, }}$ meeting the ISG-8, Rev. 3, criterion.

Detailed FP\&MA worth results for each code and nuclear data combination are provided in Appendix C.

Note that all MCNP calculations were performed with the MCNP5, v1.60, and MCNP6 codes and nuclear data distributed by the MCNP developers. Since the neutron absorption reaction in FP\&MA is the only significant interaction of neutrons with FP\&MA nuclides and the simulation of neutron capture is straightforward, the FP\&MA worth results are not affected by which MCNP version is used. Review of the data in Table 4.1 reveals that FP\&MA worths calculated using MCNP5 and MCNP6 using the same nuclear data set are statistically the same (i.e. vary by less than one or two standard deviations). Consequently, the conclusion concerning the application of the SCALE FP\&MA uncertainty information to MCNP calculation $k_{\text {eff }}$ values is not MCNP version specific. However, the conclusions may not be applicable to special MCNP versions and/or data that were not generated by the MCNP developers. 


\section{SUMMARY AND CONCLUSIONS}

The criticality safety of SNF in transportation or storage systems relies on the accurate calculation of the $k_{\text {eff }}$ values. Validation studies are used to establish the relationship between the actual and calculated $k_{\text {eff }}$ values. Unfortunately, insufficient critical experiment data is available to support use of the conventional validation approach for fission products and minor actinides in BUC criticality safety evaluations for PWR SNF casks. Work documented in NUREG/CR-7109 (Ref. 1) supports the use of nuclear data uncertainty to provide a bounding estimate of the potential bias associated with taking credit for FP\&MA in burnup credit criticality analyses. Based on that work, NRC Division of Spent Fuel Management Interim Staff Guidance 8, Rev. 3, Recommendation 4, provides guidance for adoption of a bias term equal to $1.5 \%$ or $3.0 \%$ of the FP\&MA worth, depending on the code and nuclear data used.

The work documented in this report provides justification for use of $1.5 \%$ of the FP\&MA worth as a bias in BUC criticality safety evaluations using MCNP with the ENDF/B-V, -VI, -VII or -VII.1 nuclear data distributed with those code systems by the MCNP development team. For other code systems or nuclear data sets, it may be possible to use the same method to confirm that their computational method yields FP\&MA worths similar to those calculated using the SCALE 6.1 CSAS5 sequence and the ENDF/B-VII 238 neutron energy group nuclear data library.

Section 2 of this report provides complete descriptions of the reference cask model, including dimensions, materials, and SNF compositions. These models were used to calculate FP\&MA worths using MCNP and its ENDF/B-V, -VI, -VII and -VII.1 data. These FP\&MA worths are compared with the reference SCALE results to show that they are similar.

The results generated using MCNP with multiple sets of nuclear data are presented in Section 4. All nuclear data sets examined yielded FP\&MA worths that were within $1.7 \%$ of the reference FP\&MA worths. The MCNP results were no greater than $0.7 \%$ larger than the reference FP\&MA worths for any of the burnup, decay time, and nuclear data libraries considered. Consequently, use of the $1.5 \%$ of FP\&MA worth bias to account for poor validation of FP\&MAs in criticality calculations performed using MCNP5 or MCNP6 with ENDF/B-V, $-\mathrm{VI}$, - VII or - VII.1 data is recommended. 



\section{REFERENCES}

1. J. M. Scaglione, et al., An Approach for Validating Actinide and Fission Product Burnup Credit Criticality Analyses - Criticality $\left(k_{\text {eff }}\right)$ Predictions, NUREG/CR-7109 (ORNL/TM2011/514), prepared for the U.S. Nuclear Regulatory Commission by Oak Ridge National Laboratory, Oak Ridge, Tenn., April 2012.

2. Division of Spent Fuel Storage and Transportation, Interim Staff Guidance-8, Rev. 3, Burnup Credit in the Criticality Analyses of PWR Spent Fuel in Transportation and Storage Casks, U.S. Nuclear Regulatory Commission, September 27, 2012.

3. Scale: A Comprehensive Modeling and Simulation Suite for Nuclear Safety Analysis and Design, ORNL/TM-2005/39, Version 6.1, Oak Ridge National Laboratory, Oak Ridge, Tenn. June 2011. Available from Radiation Safety Information Computational Center at Oak Ridge National Laboratory as CCC-785.

4. MCNP - A General Monte Carlo N-Particle Transport Code, Version 5, LA-UR-03-1987, Los Alamos National Laboratory, Los Alamos, N.M., February 1, 2008. Available from Radiation Safety Information and Computational Center at Oak Ridge National Laboratory as CCC-740.

5. J. C. Wagner, Computational Benchmark for Estimation of Reactivity Margin from Fission Products and Minor Actinides in PWR Burnup Credit, NUREG/CR-6747 (ORNL/TM2000/306), prepared for the U.S. Nuclear Regulatory Commission by Oak Ridge National Laboratory, Oak Ridge, Tenn., October 2001.

6. C. D. Harmon II, et al., Criticality Calculations with MCNP: A Primer, LA-12827-M, Los Alamos National Laboratory, Los Alamos, N.M., 1994.

7. J. J. Duderstadt and L. J. Hamilton, Nuclear Reactor Analysis, John Wiley \& Sons, 1976.

8. Boral-The Proven Neutron Absorber, AAR Advanced Structures, Livonia, Michigan.

9. Standard Review Plan for Spent Fuel Dry Storage Systems at a General License Facility, NUREG-1536, Revision 1, U.S. Nuclear Regulatory Commission, Washington, D.C., July 2010.

10. RW-859 Nuclear Fuel Data, Energy Information Administration, Washington, D.C., October 2004.

11. J. C. Wagner, M. D. DeHart, and C. V. Parks, Recommendations for Addressing Axial Burnup in PWR Burnup Credit Analyses, NUREG/CR-6801 (ORNL/TM-2001/273) prepared for the U.S. Nuclear Regulatory Commission by Oak Ridge National Laboratory, Oak Ridge, Tenn., March 2003. 



\section{APPENDIX A. SCALE 6.1 CSAS5 MODEL}

This appendix includes a SCALE 6.1 CSAS5 model and spent nuclear fuel composition information in the SCALE input format for fuel burned to $20 \mathrm{GWd} / \mathrm{MTU}$, following a 5year post-irradiation cooling time. Composition inputs for other burnup/cooling time combinations are provided following this CSAS5 input file.

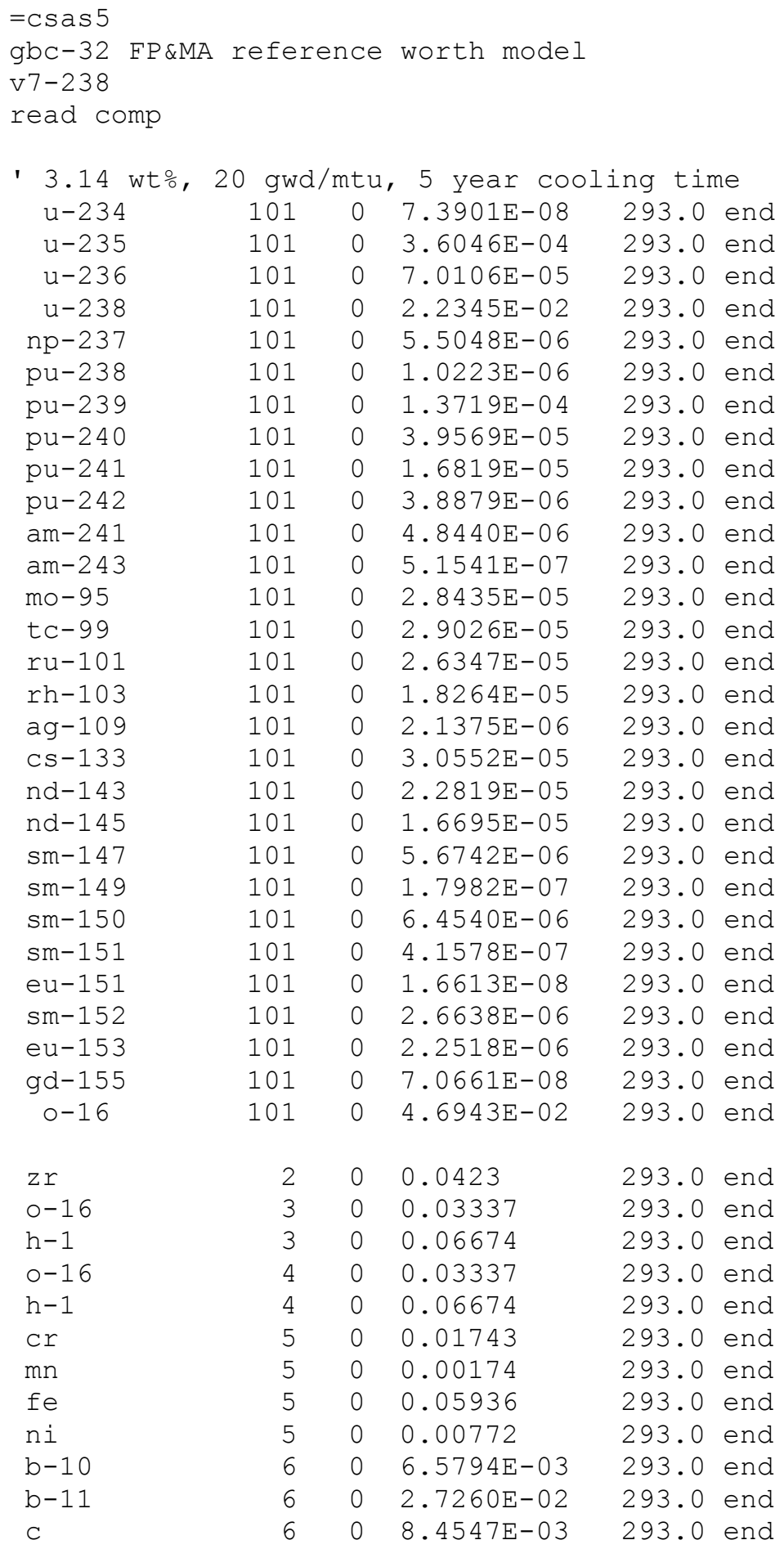




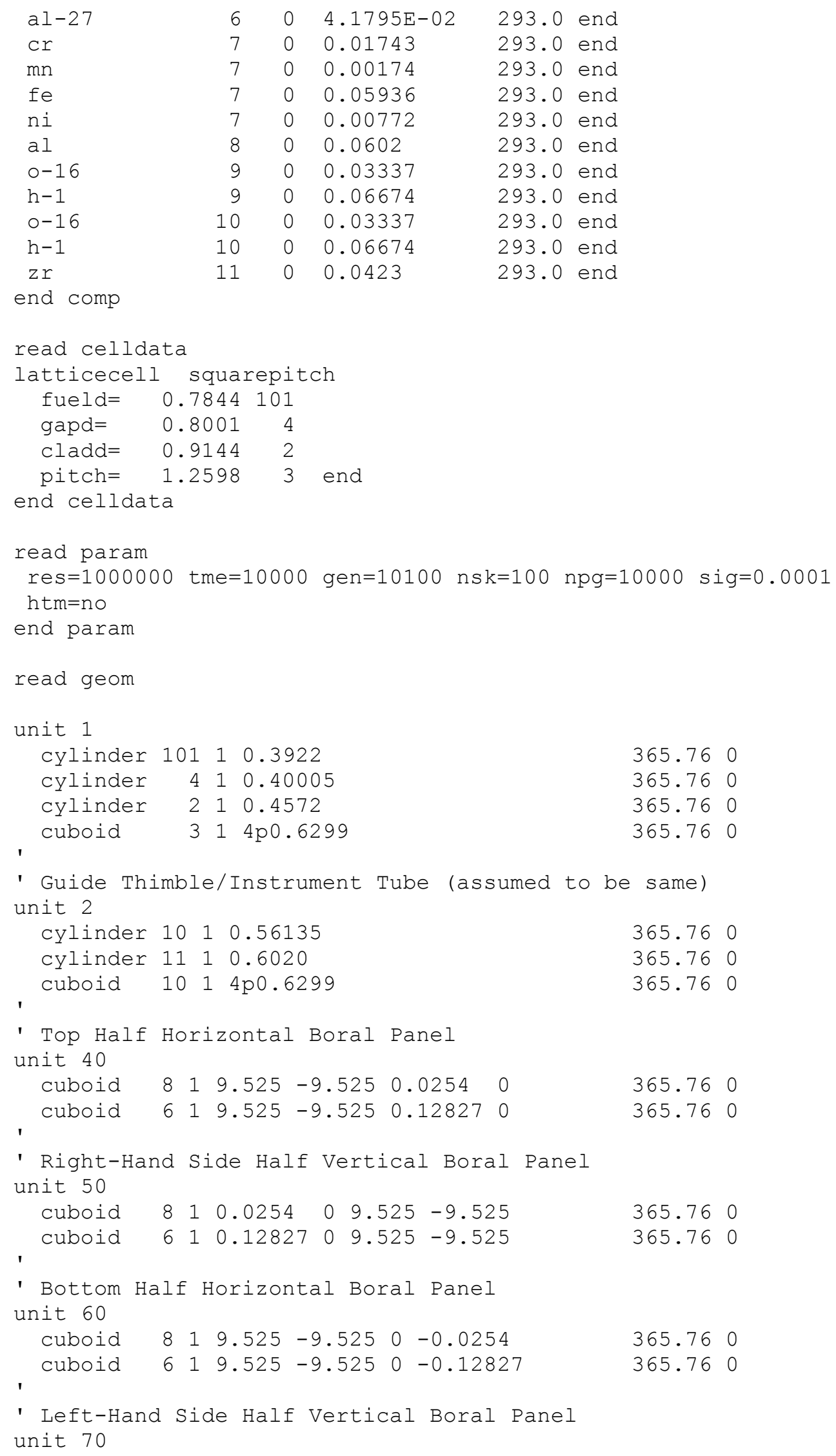




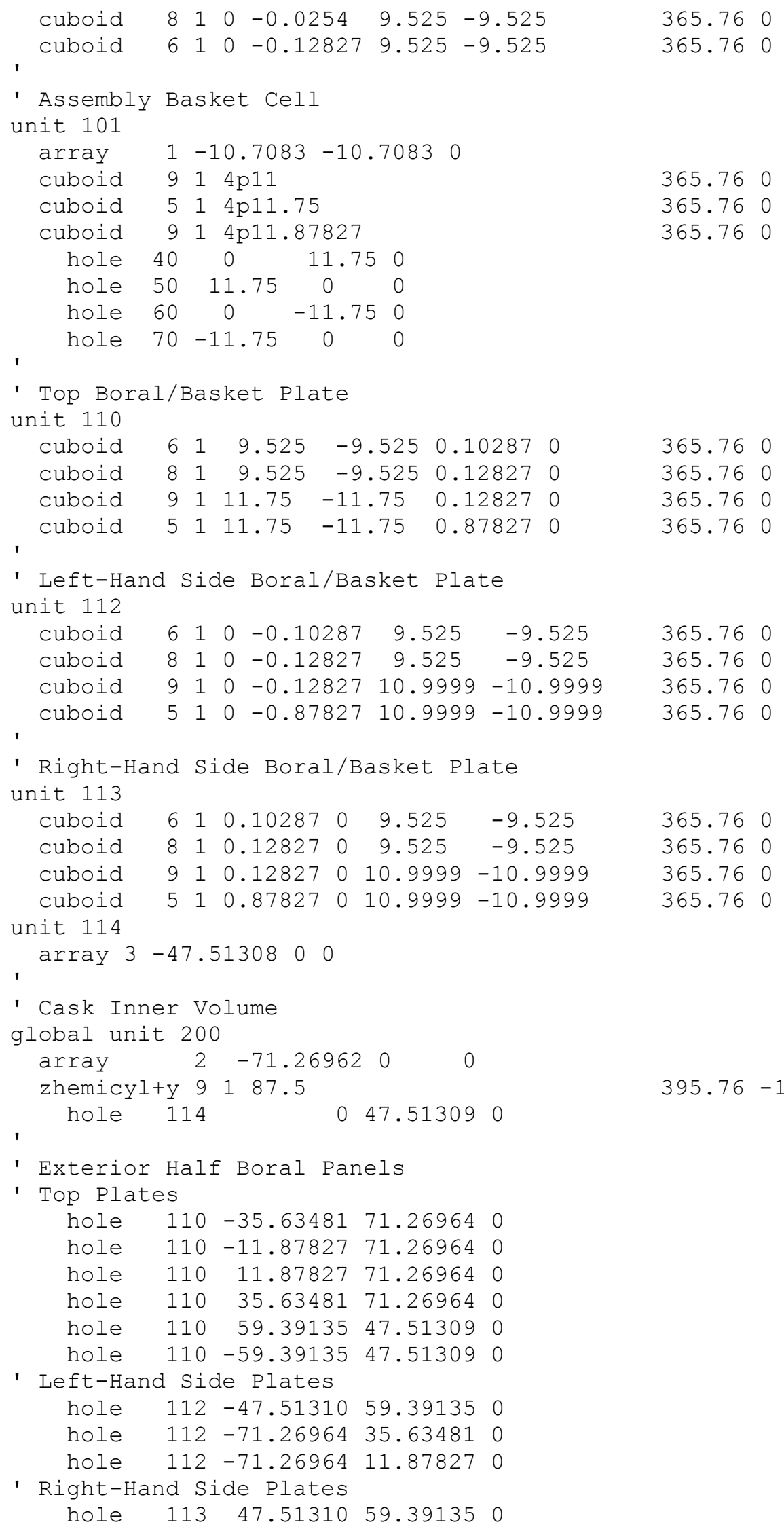




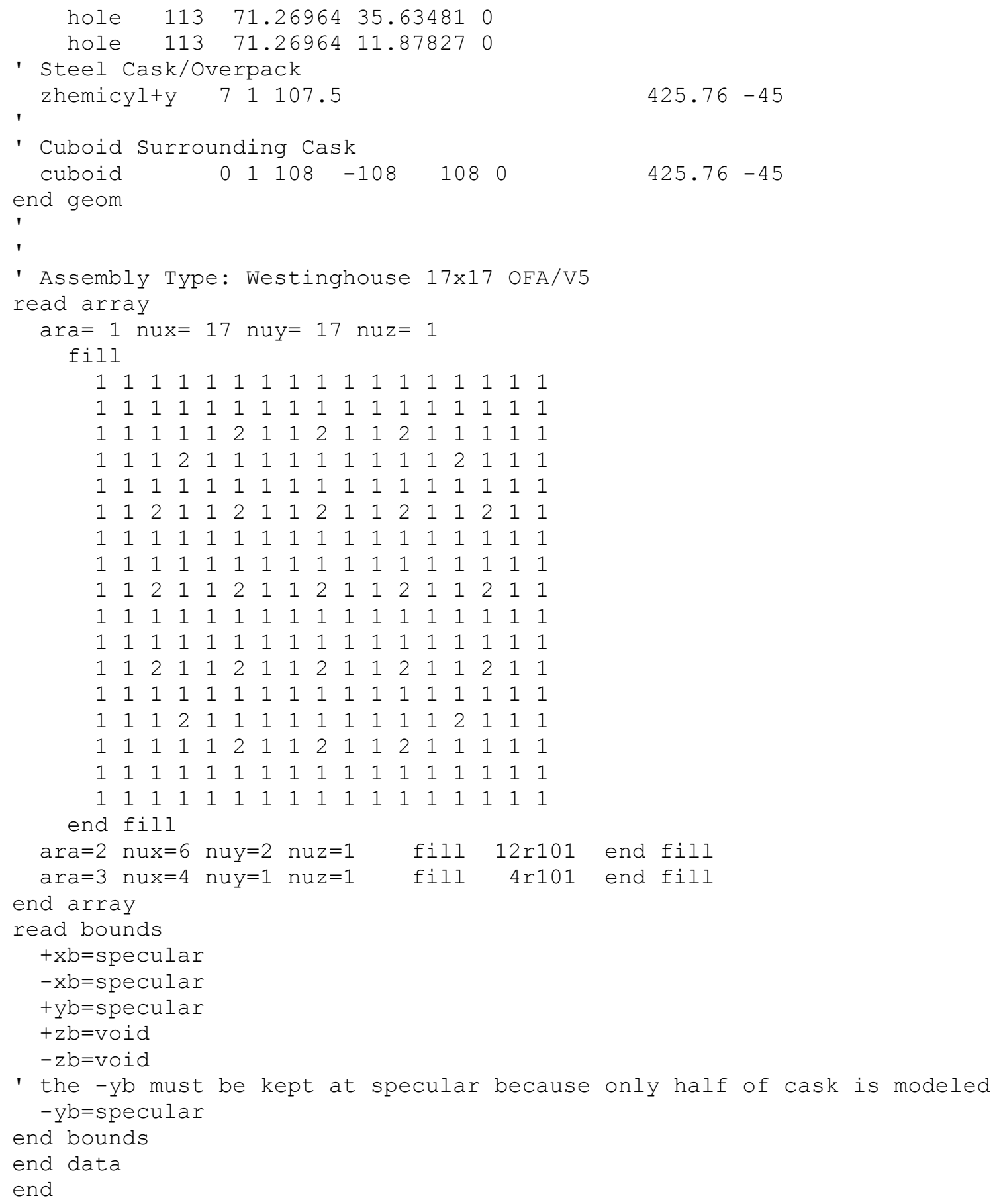


Composition input for fuel burned to $20 \mathrm{GWd} / \mathrm{MTU}$, following a 40 -year cooling time.

Replaces composition 101 provided in the above generic burnup credit-32 (GBC-32) cask model input file.

\begin{tabular}{|c|c|c|c|c|}
\hline$u-234$ & 101 & 0 & $3.2108 E-07$ & 293.0 \\
\hline$u-235$ & 101 & 0 & $3.6060 \mathrm{E}-04$ & 293.0 \\
\hline$u-236$ & 101 & 0 & $7.0252 \mathrm{E}-05$ & 293.0 \\
\hline$u-238$ & 101 & 0 & $2.2345 E-02$ & 293.0 \\
\hline$n p-237$ & 101 & 0 & $6.2485 E-06$ & 293.0 \\
\hline pu-238 & 101 & 0 & $7.7547 \mathrm{E}-07$ & 293.0 \\
\hline pu-239 & 101 & 0 & $1.3705 \mathrm{E}-04$ & 293.0 \\
\hline$p u-240$ & 101 & 0 & $3.9477 \mathrm{E}-05$ & 293.0 \\
\hline pu-241 & 101 & 0 & $3.0797 \mathrm{E}-06$ & 293.0 \\
\hline pu-242 & 101 & 0 & $3.8877 \mathrm{E}-06$ & 293.0 \\
\hline$a m-241$ & 101 & 0 & $1.7840 \mathrm{E}-05$ & 293.0 \\
\hline$a m-243$ & 101 & 0 & $5.1371 \mathrm{E}-07$ & 293.0 \\
\hline mo-95 & 101 & 0 & $2.8435 E-05$ & 293.0 \\
\hline tc -99 & 101 & 0 & $2.9023 E-05$ & 293.0 \\
\hline ru-101 & 101 & 0 & $2.6347 \mathrm{E}-05$ & 293.0 \\
\hline rh-103 & 101 & 0 & $1.8264 \mathrm{E}-05$ & 293.0 \\
\hline ag-109 & 101 & 0 & $2.1375 \mathrm{E}-06$ & 293.0 \\
\hline$c s-133$ & 101 & 0 & $3.0552 \mathrm{E}-05$ & 3.0 \\
\hline nd -143 & 101 & 0 & $2.2819 \mathrm{E}-05$ & 293.0 \\
\hline nd -145 & 101 & 0 & $1.6695 \mathrm{E}-05$ & 293.0 \\
\hline sm-147 & 101 & 0 & $7.4723 E-06$ & 293.0 \\
\hline$s m-149$ & 101 & 0 & $1.7982 \mathrm{E}-07$ & 293.0 \\
\hline$s m-150$ & 101 & 0 & $6.4540 \mathrm{E}-06$ & 293.0 \\
\hline $\mathrm{sm}-151$ & 101 & 0 & $3.1754 \mathrm{E}-07$ & 293.0 \\
\hline eu-151 & 101 & 0 & $1.1485 \mathrm{E}-07$ & 293.0 \\
\hline$s m-152$ & 101 & 0 & $2.6639 \mathrm{E}-06$ & 293.0 \\
\hline eu-153 & 101 & 0 & $2.2518 \mathrm{E}-06$ & 293.0 \\
\hline$g d-155$ & 101 & 0 & $1.3548 \mathrm{E}-07$ & 3.0 \\
\hline $0-16$ & 101 & 0 & $4.6943 \mathrm{E}-02$ & \\
\hline
\end{tabular}


Composition input for fuel burned to $\mathbf{4 0} \mathrm{GWd} / \mathrm{MTU}$, following a 5-year cooling time.

Replaces composition 101 provided in the above GBC-32 input file.

\begin{tabular}{|c|c|c|c|c|}
\hline$u-234$ & 101 & 0 & $2.6245 \mathrm{E}-07$ & 293.0 \\
\hline$u-235$ & 101 & 0 & $3.6741 \mathrm{E}-04$ & 293.0 \\
\hline$u-236$ & 101 & 0 & $1.3508 \mathrm{E}-04$ & 293.0 \\
\hline$u-238$ & 101 & 0 & $2.1683 \mathrm{E}-02$ & 293.0 \\
\hline$n p-237$ & 101 & 0 & $1.3907 \mathrm{E}-05$ & 293.0 \\
\hline pu-238 & 101 & 0 & $4.5238 \mathrm{E}-06$ & 293.0 \\
\hline$p u-239$ & 101 & 0 & $1.7413 \mathrm{E}-04$ & 293.0 \\
\hline$p u-240$ & 101 & 0 & $6.3031 E-05$ & 293.0 \\
\hline pu-241 & 101 & 0 & $3.2475 \mathrm{E}-05$ & 293.0 \\
\hline pu-242 & 101 & 0 & $1.1666 \mathrm{E}-05$ & 293.0 \\
\hline$a m-241$ & 101 & 0 & $9.7110 \mathrm{E}-06$ & 293.0 \\
\hline$a m-243$ & 101 & 0 & $2.5940 \mathrm{E}-06$ & 293.0 \\
\hline mo-95 & 101 & 0 & $5.4717 \mathrm{E}-05$ & 293.0 \\
\hline tc-99 & 101 & 0 & $5.5148 \mathrm{E}-05$ & 293.0 \\
\hline ru-101 & 101 & 0 & $5.1618 \mathrm{E}-05$ & 293.0 \\
\hline rh-103 & 101 & 0 & $3.1900 \mathrm{E}-05$ & 293.0 \\
\hline ag-109 & 101 & 0 & $4.3961 \mathrm{E}-06$ & 293.0 \\
\hline Cs -133 & 101 & 0 & $5.7163 \mathrm{E}-05$ & 3.0 \\
\hline$n d-143$ & 101 & 0 & $4.1309 \mathrm{E}-05$ & 293.0 \\
\hline nd -145 & 101 & 0 & $3.1395 \mathrm{E}-05$ & 293.0 \\
\hline sm-147 & 101 & 0 & $9.3467 \mathrm{E}-06$ & 293.0 \\
\hline$s m-149$ & 101 & 0 & $2.2875 \mathrm{E}-07$ & 293.0 \\
\hline $\mathrm{sm}-150$ & 101 & 0 & $1.3517 \mathrm{E}-05$ & 293.0 \\
\hline$s m-151$ & 101 & 0 & $6.4777 \mathrm{E}-07$ & 293.0 \\
\hline eu-151 & 101 & 0 & $2.5993 \mathrm{E}-08$ & 293.0 \\
\hline$s m-152$ & 101 & 0 & $4.2868 \mathrm{E}-06$ & 293.0 \\
\hline eu-153 & 101 & 0 & $4.9812 \mathrm{E}-06$ & 293.0 \\
\hline$g d-155$ & 101 & 0 & $1.7686 \mathrm{E}-07$ & 293.0 \\
\hline $0-16$ & 101 & 0 & $4.6949 \mathrm{E}-02$ & 3.0 \\
\hline
\end{tabular}


Composition input for fuel burned to $40 \mathrm{GWd} / \mathrm{MTU}$, following a 40 -year cooling time.

Replaces composition 101 provided in the above GBC-32 input file.

\begin{tabular}{|c|c|c|c|c|}
\hline$u-234$ & 101 & 0 & $1.3559 \mathrm{E}-06$ & 293.0 \\
\hline$u-235$ & 101 & 0 & $3.6758 \mathrm{E}-04$ & 293.0 \\
\hline$u-236$ & 101 & 0 & $1.3532 \mathrm{E}-04$ & 293.0 \\
\hline$u-238$ & 101 & 0 & $2.1683 \mathrm{E}-02$ & 293.0 \\
\hline$n p-237$ & 101 & 0 & $1.5362 \mathrm{E}-05$ & 293.0 \\
\hline pu-238 & 101 & 0 & $3.4316 \mathrm{E}-06$ & 293.0 \\
\hline$p u-239$ & 101 & 0 & $1.7396 \mathrm{E}-04$ & 293.0 \\
\hline$p u-240$ & 101 & 0 & $6.3301 \mathrm{E}-05$ & 293.0 \\
\hline pu-241 & 101 & 0 & $5.9464 \mathrm{E}-06$ & 293.0 \\
\hline pu-242 & 101 & 0 & $1.1665 \mathrm{E}-05$ & 293.0 \\
\hline$a m-241$ & 101 & 0 & $3.4784 \mathrm{E}-05$ & 293.0 \\
\hline$a m-243$ & 101 & 0 & $2.5854 \mathrm{E}-06$ & 293.0 \\
\hline mo-95 & 101 & 0 & $5.4717 \mathrm{E}-05$ & 293.0 \\
\hline tc-99 & 101 & 0 & $5.5142 \mathrm{E}-05$ & 293.0 \\
\hline ru-101 & 101 & 0 & $5.1618 \mathrm{E}-05$ & 293.0 \\
\hline rh-103 & 101 & 0 & $3.1900 \mathrm{E}-05$ & 293.0 \\
\hline ag-109 & 101 & 0 & $4.3961 \mathrm{E}-06$ & 293.0 \\
\hline Cs -133 & 101 & 0 & $5.7163 \mathrm{E}-05$ & 3.0 \\
\hline nd -143 & 101 & 0 & $4.1309 \mathrm{E}-05$ & 293.0 \\
\hline$n d-145$ & 101 & 0 & $3.1395 \mathrm{E}-05$ & 293.0 \\
\hline sm-147 & 101 & 0 & $1.1950 \mathrm{E}-05$ & 293.0 \\
\hline$s m-149$ & 101 & 0 & $2.2875 \mathrm{E}-07$ & 293.0 \\
\hline $\mathrm{sm}-150$ & 101 & 0 & $1.3517 \mathrm{E}-05$ & 293.0 \\
\hline$s m-151$ & 101 & 0 & $4.9471 \mathrm{E}-07$ & 293.0 \\
\hline eu-151 & 101 & 0 & $1.7905 \mathrm{E}-07$ & 293.0 \\
\hline$s m-152$ & 101 & 0 & $4.2871 \mathrm{E}-06$ & 293.0 \\
\hline eu-153 & 101 & 0 & $4.9812 \mathrm{E}-06$ & 293.0 \\
\hline$g d-155$ & 101 & 0 & $3.3841 \mathrm{E}-07$ & 293.0 \\
\hline $0-16$ & 101 & 0 & $4.6949 \mathrm{E}-02$ & \\
\hline
\end{tabular}





\section{APPENDIX B. MCNP MODEL}

This appendix includes a MCNP model and spent nuclear fuel composition information in the MCNP input format for fuel burned to $20 \mathrm{GWd} / \mathrm{MTU}$, following a 5-year post-irradiation cooling time. Composition inputs for other burnup/cooling time combinations are provided following this MCNP input file.

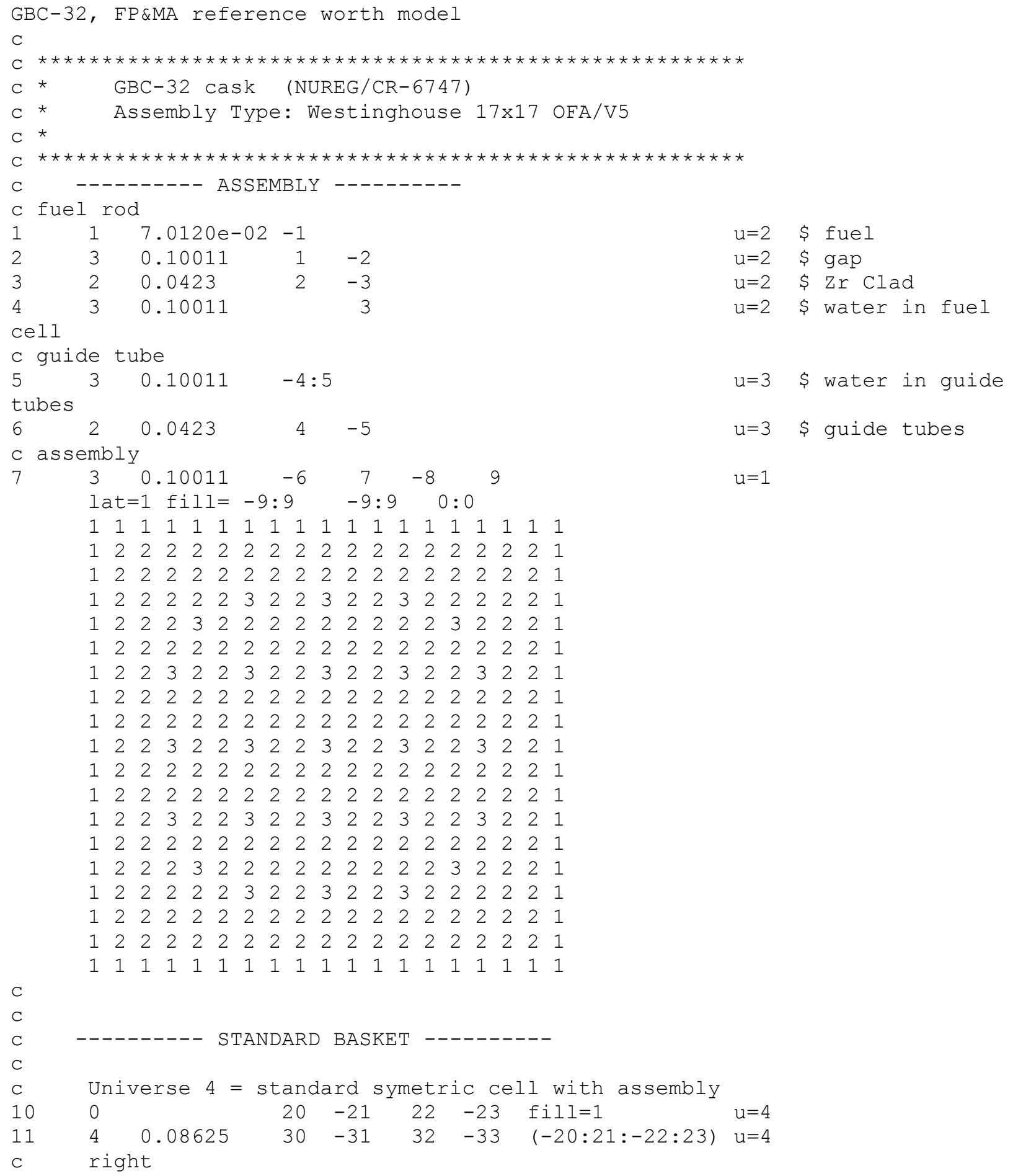




\begin{tabular}{|c|c|c|c|c|c|c|c|c|c|}
\hline 20 & 3 & 0.10011 & 31 & & & & $\# 21 \quad \# 22$ & $\mathrm{u}=4$ & \$ Water \\
\hline 21 & 7 & 0.0602 & 31 & -41 & 12 & -13 & & $\mathrm{u}=4$ & \$Al Boral Clad \\
\hline 22 & 5 & 0.084089 & 41 & & 12 & -13 & & $u=4$ & \$ Boral Center \\
\hline c & \multicolumn{9}{|c|}{ left } \\
\hline 30 & 3 & 0.10011 & -30 & & & & \multirow{3}{*}{ \#31 \#32 } & $u=4$ & \$ Water \\
\hline 31 & 7 & 0.0602 & -30 & 40 & 12 & -13 & & $u=4$ & \$Al Boral Clad \\
\hline 32 & 5 & 0.084089 & -40 & & 12 & -13 & & $u=4$ & \$ Boral Center \\
\hline $\mathrm{C}$ & tor & & & & & & & & \\
\hline 40 & 3 & 0.10011 & 33 & & 30 & -31 & \multirow[t]{3}{*}{$\# 41 \quad \# 42$} & $u=4$ & \$ Water \\
\hline 41 & 7 & 0.0602 & 33 & -43 & 10 & -11 & & $u=4$ & \$Al Boral Clad \\
\hline 42 & 5 & 0.084089 & 43 & & 10 & -11 & & $u=4$ & \$ Boral Center \\
\hline C & \multicolumn{9}{|c|}{ bottom } \\
\hline 50 & 3 & 0.10011 & -32 & & 30 & -31 & \multirow[t]{3}{*}{ \#51 \#52 } & $u=4$ & \multirow{3}{*}{$\begin{array}{l}\text { Water } \\
\$ \text { Al Bor } \\
\$ \text { Boral }\end{array}$} \\
\hline 51 & 7 & 0.0602 & -32 & 42 & 10 & -11 & & $u=4$ & \\
\hline 52 & 5 & 0.084089 & -42 & & 10 & -11 & & $u=4$ & \\
\hline \multirow{2}{*}{\multicolumn{10}{|c|}{ c }} \\
\hline & & & & & & & & & \\
\hline ( & \multirow{2}{*}{\multicolumn{3}{|c|}{---------- PERIPHERY }} & BASK & $\mathrm{KET} / \mathrm{PO}$ & OISON P & \multirow{2}{*}{\multicolumn{3}{|c|}{ PLATES --------- }} \\
\hline c & & & & & & & & & \\
\hline C & \multirow{2}{*}{\multicolumn{7}{|c|}{$\begin{array}{l}\text { Universe } 5=\text { top cell, which has boral on bottom } \\
30.10011 \quad 22\end{array}$}} & \multirow{2}{*}{\multicolumn{2}{|c|}{$u=5$}} \\
\hline 100 & & & & & & & & & \\
\hline 101 & 3 & 0.10011 & -22 & & & & \multirow{2}{*}{ \#102 \#103 \#104 } & $u=5$ & \\
\hline 102 & 4 & 0.08625 & 30 & -31 & -22 & 32 & & $u=5$ & \\
\hline 103 & 7 & 0.0602 & -32 & 42 & 10 & -11 & & $u=5$ & \$ Al Boral Clad \\
\hline 104 & 5 & 0.084089 & -42 & & 10 & -11 & & $u=5$ & \$ Boral Center \\
\hline C & & & & & & & & & \\
\hline C & \multirow{2}{*}{\multicolumn{7}{|c|}{$\begin{array}{l}\text { Universe } 6=\text { bottom cell, which has boral on top } \\
30.10011-23\end{array}$}} & \multirow{2}{*}{\multicolumn{2}{|c|}{$u=6$}} \\
\hline 110 & & & & & & & & & \\
\hline 111 & 3 & 0.10011 & 23 & & & & \multirow{2}{*}{ \#112 \#113 \#114 } & $u=6$ & \\
\hline 112 & 4 & 0.08625 & 30 & -31 & 23 & -33 & & $u=6$ & \\
\hline 113 & 7 & 0.0602 & 33 & -43 & 10 & -11 & & $u=6$ & \$ Al Boral Clad \\
\hline 114 & 5 & 0.084089 & 43 & & 10 & -11 & & $u=6$ & \$ Boral Center \\
\hline C & & & & & & & & & \\
\hline C & Un: & verse $7=$ & right- & hand & side & cell, & which has boral & 1 on & left-hand side \\
\hline $12 c$ & 3 & 0.10011 & 20 & & & & & $u=7$ & \\
\hline 121 & 3 & 0.10011 & -20 & & & & \#122 \#123 \#124 & $u=7$ & \\
\hline 122 & 4 & 0.08625 & 22 & -23 & -20 & 30 & & $u=7$ & \\
\hline 123 & 7 & 0.0602 & -30 & 40 & 12 & -13 & & $u=7$ & \$Al Boral Clad \\
\hline 124 & 5 & 0.084089 & -40 & & 12 & -13 & & $u=7$ & \$ Boral Center \\
\hline $\mathrm{C}$ & & & & & & & & & \\
\hline c & Un & erse $8=$ & left-h & land $\mathrm{s}$ & side c & cell, w & which has boral & on $r$ & right-hand side \\
\hline 13 & 3 & 0.10011 & -21 & & & & & $u=8$ & \\
\hline 131 & 3 & 0.10011 & 21 & & & & \#132 \#133 \#134 & $u=8$ & \\
\hline 132 & 4 & 0.08625 & 22 & -23 & 21 & -31 & & $u=8$ & \\
\hline 133 & 7 & 0.0602 & 31 & -41 & 12 & -13 & & $u=8$ & \$Al Boral Clad \\
\hline 134 & 5 & 0.084089 & 41 & & 12 & -13 & & $u=8$ & \$ Boral Center \\
\hline C & & & & & & & & & \\
\hline c & & & & & & & & & \\
\hline C & --- & ---- BASI & $\mathrm{KET} \mathrm{CO}$ & RNERS & ---- & --1 & & & \\
\hline $\mathrm{C}$ & & & & & & & & & \\
\hline C & Un & verse $10=$ & top-1 & eft $c$ & corner & r cell, & , which has bora & al on & h bottom-right \\
\hline 150 & 3 & 0.10011 & -21 & 22 & & & & $u=10$ & \\
\hline 151 & 4 & 0.08625 & -31 & 32 & (21: & $:-22)$ & $\# 152$ \#153 & $u=10$ & \\
\hline 152 & 3 & 0.10011 & 21 & -31 & 23 & -53 & & $u=10$ & \\
\hline 153 & 3 & 0.10011 & 50 & -30 & 32 & -22 & & $u=10$ & \\
\hline C & ric & & & & & & & & \\
\hline 155 & 3 & 0.10011 & 31 & & & & \#156 \#157 & $u=10$ & o \$ Water \\
\hline
\end{tabular}




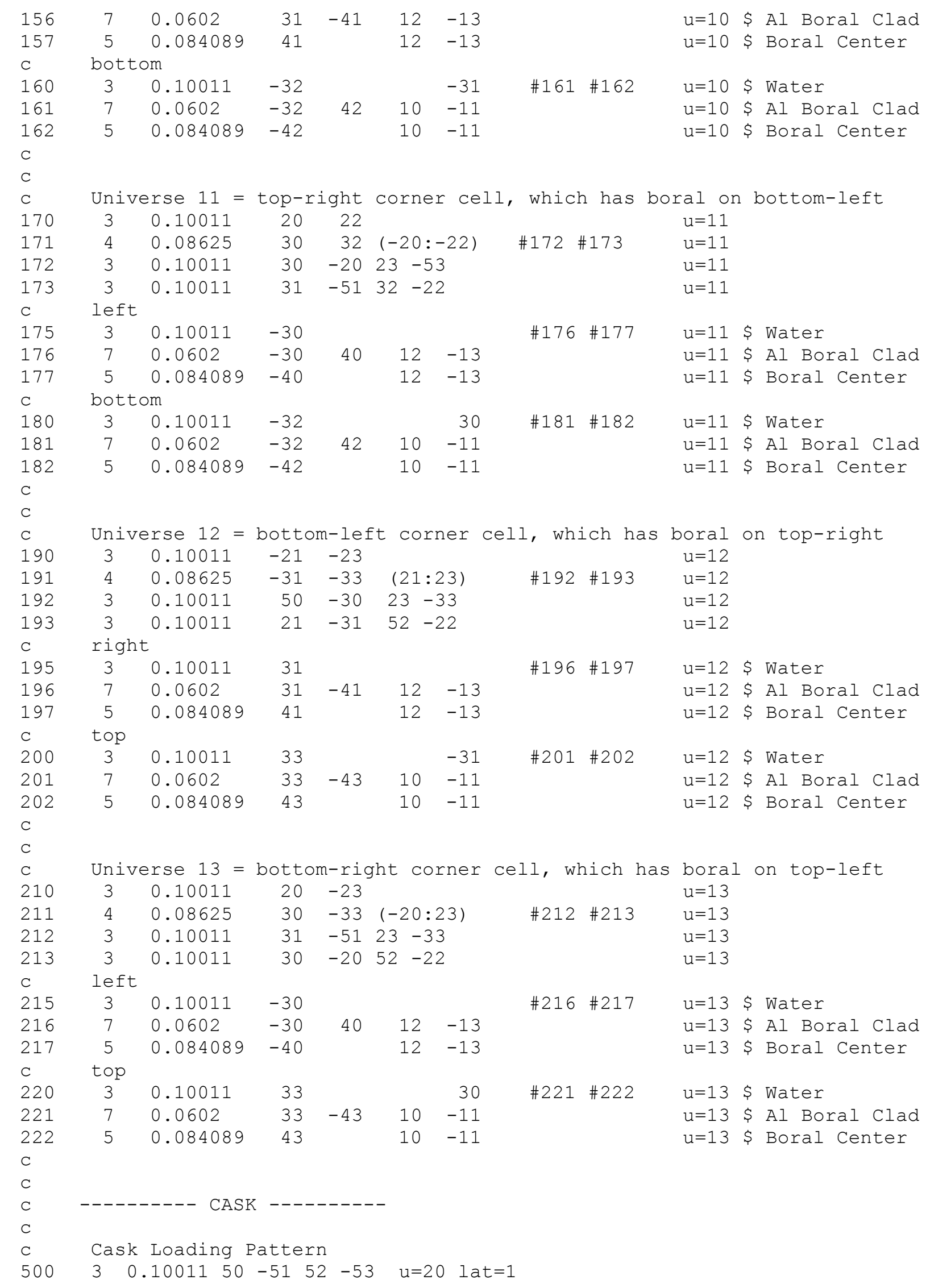




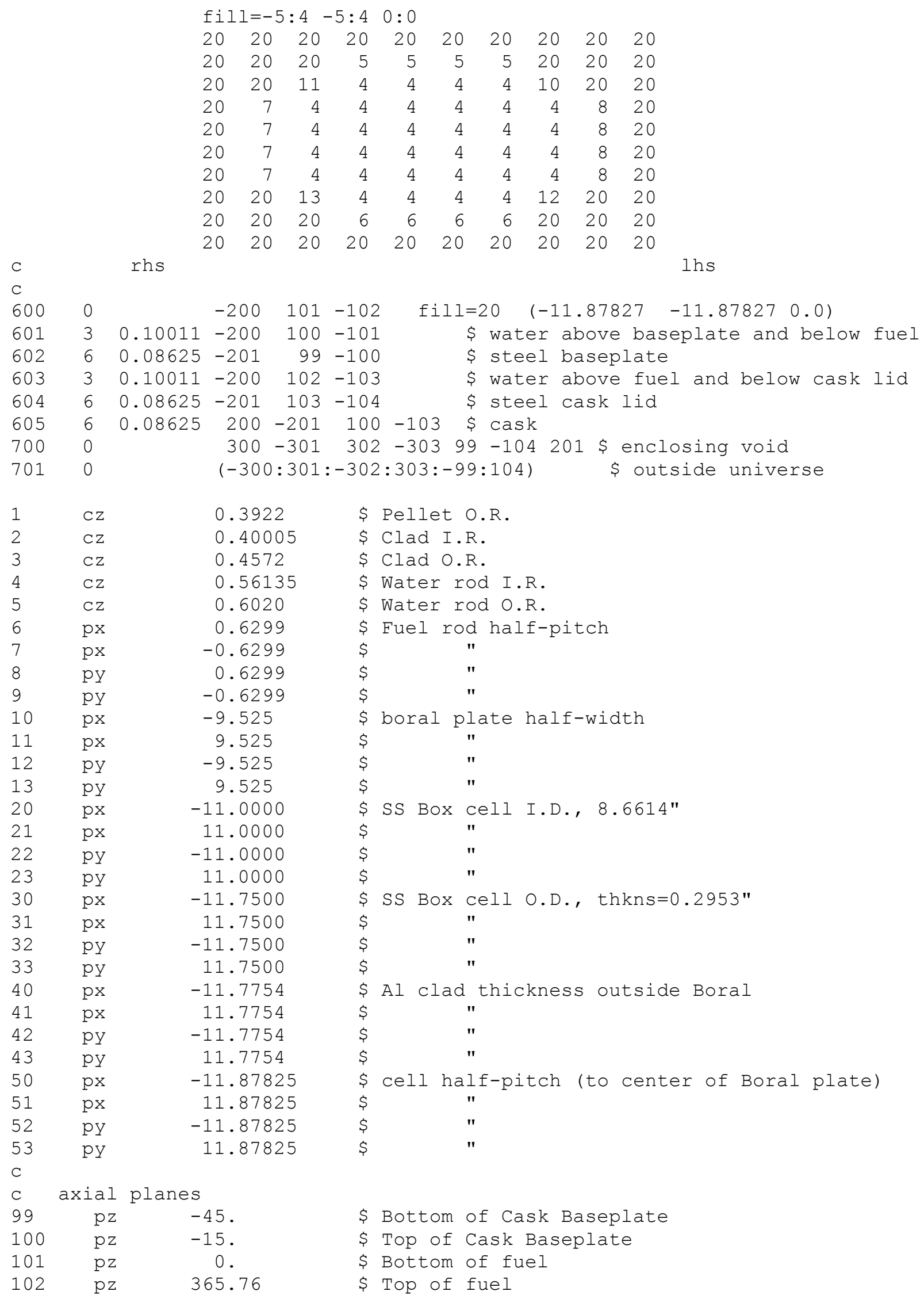




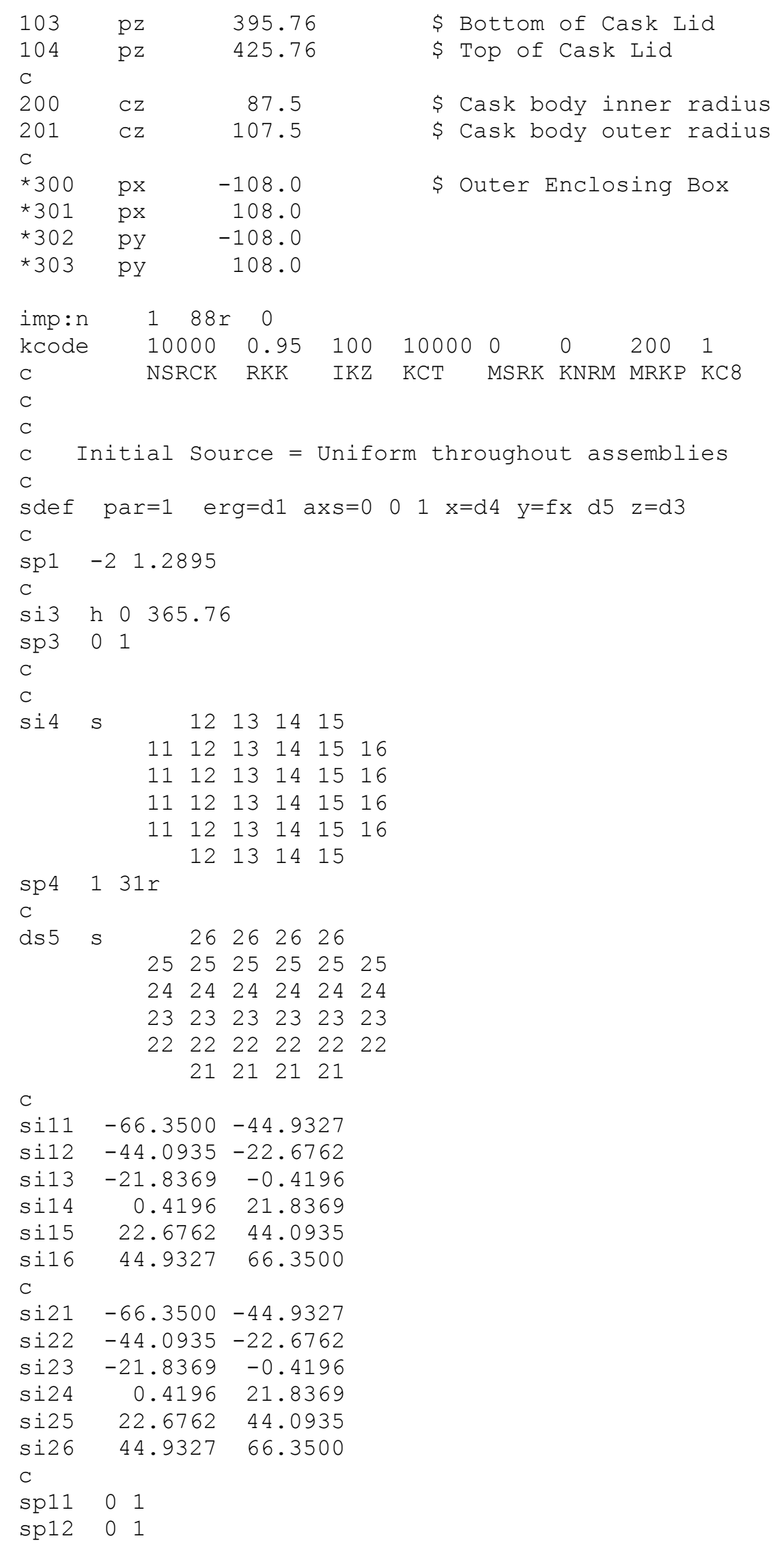




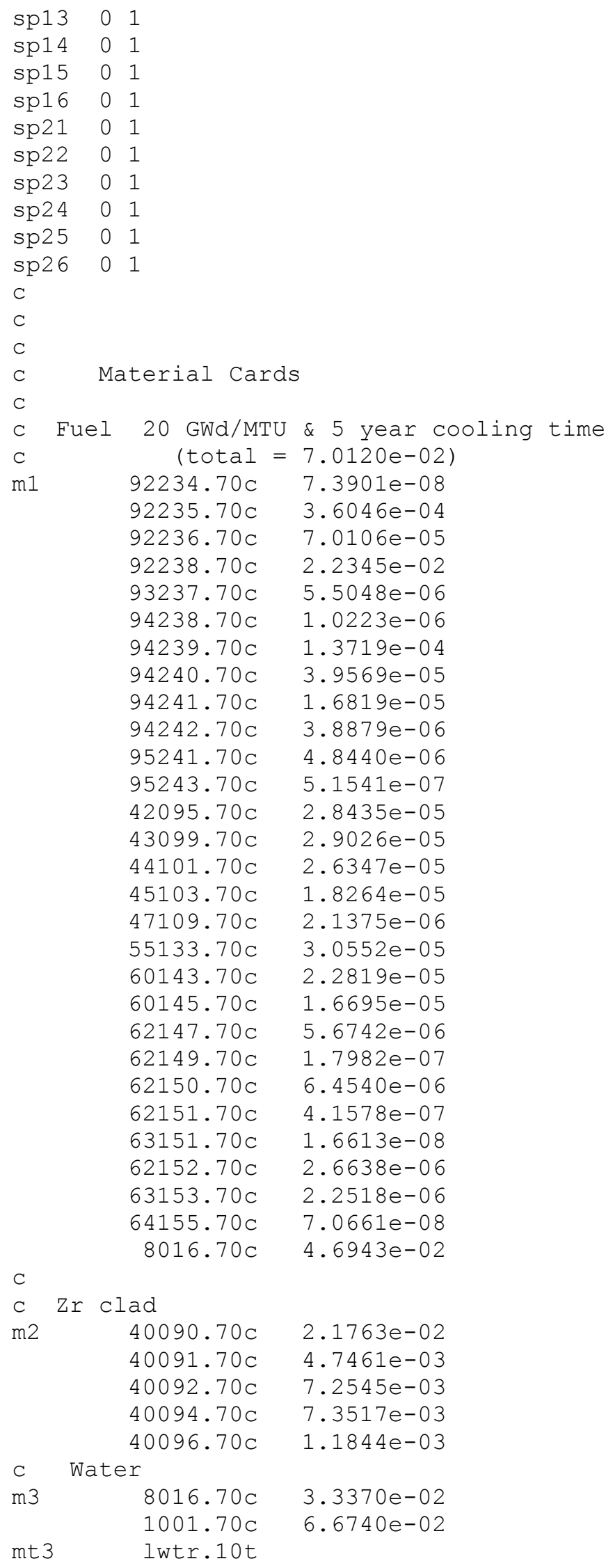




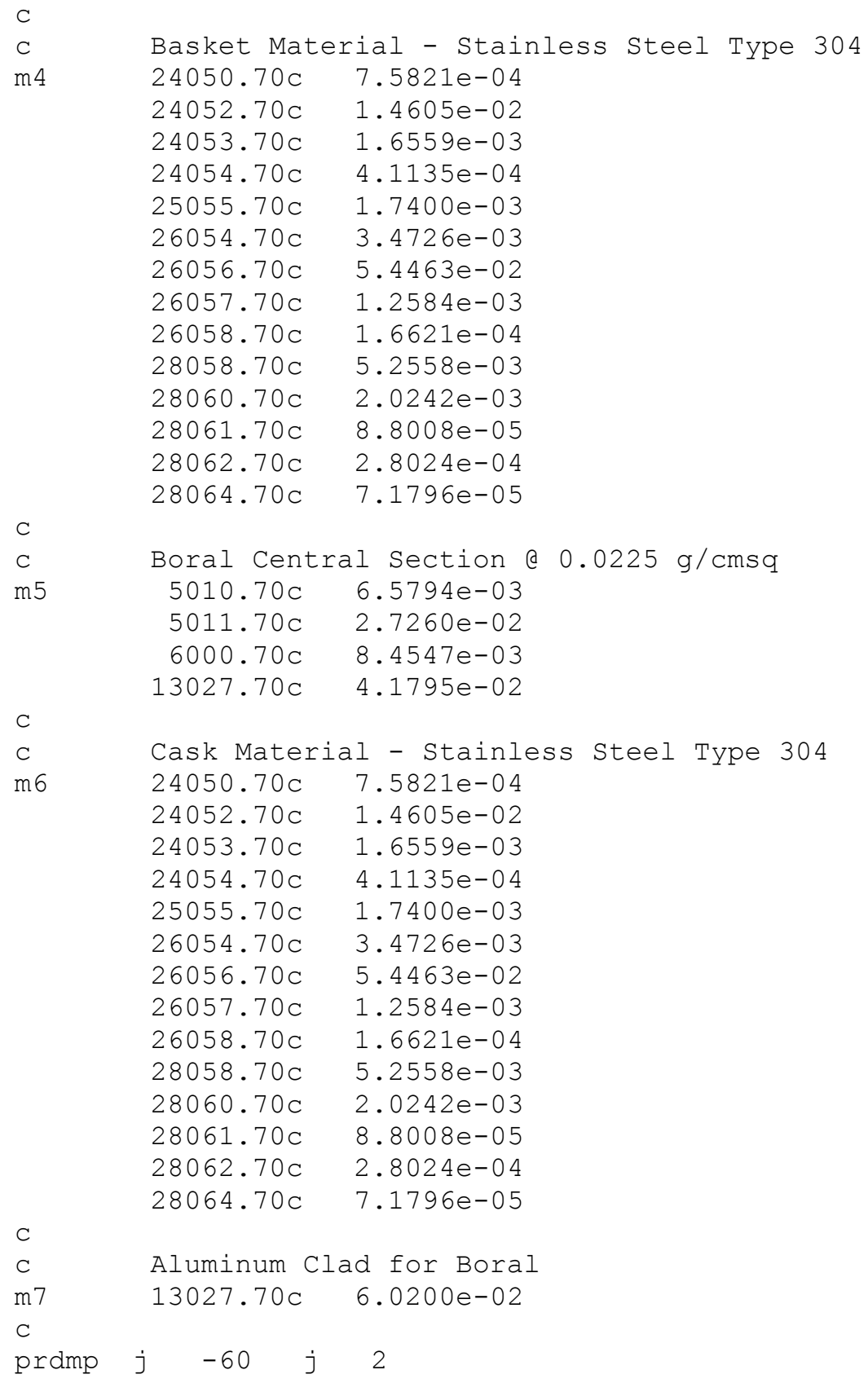


Composition input for fuel burned to $20 \mathrm{GWd} / \mathrm{MTU}$, following a 40 -year cooling time.

The total number density in cell 1 is changed to $7.0122 \mathrm{e}-02$

Replace composition $\mathrm{m} 1$ provided in the above generic burnup credit-32 (GBC-32) cask model input file.

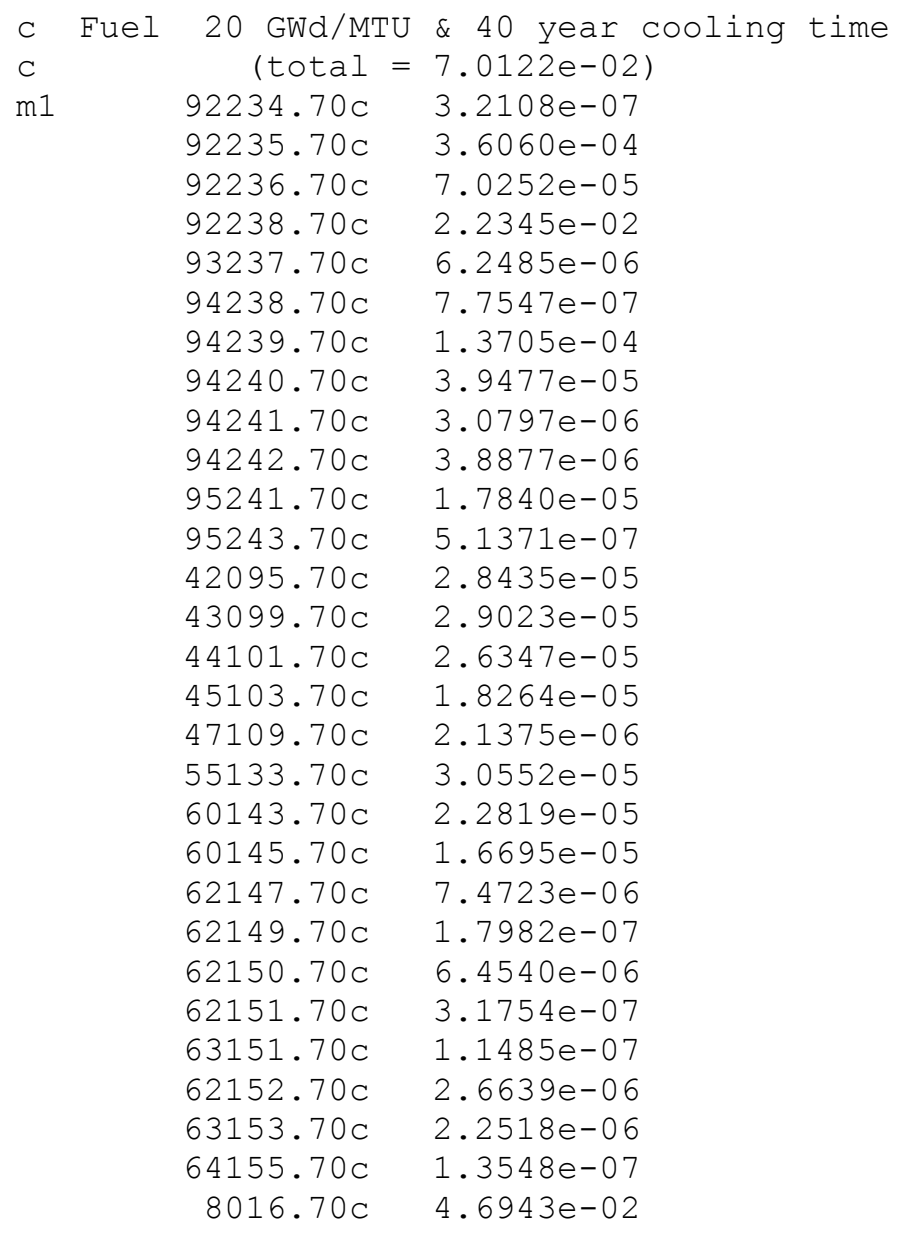


Composition input for fuel burned to $\mathbf{4 0} \mathrm{GWd} / \mathrm{MTU}$, following a 5-year cooling time.

The total number density in cell 1 is changed to $6.9808 \mathrm{e}-02$

Replace composition $\mathrm{m} 1$ provided in the above GBC-32 input file.

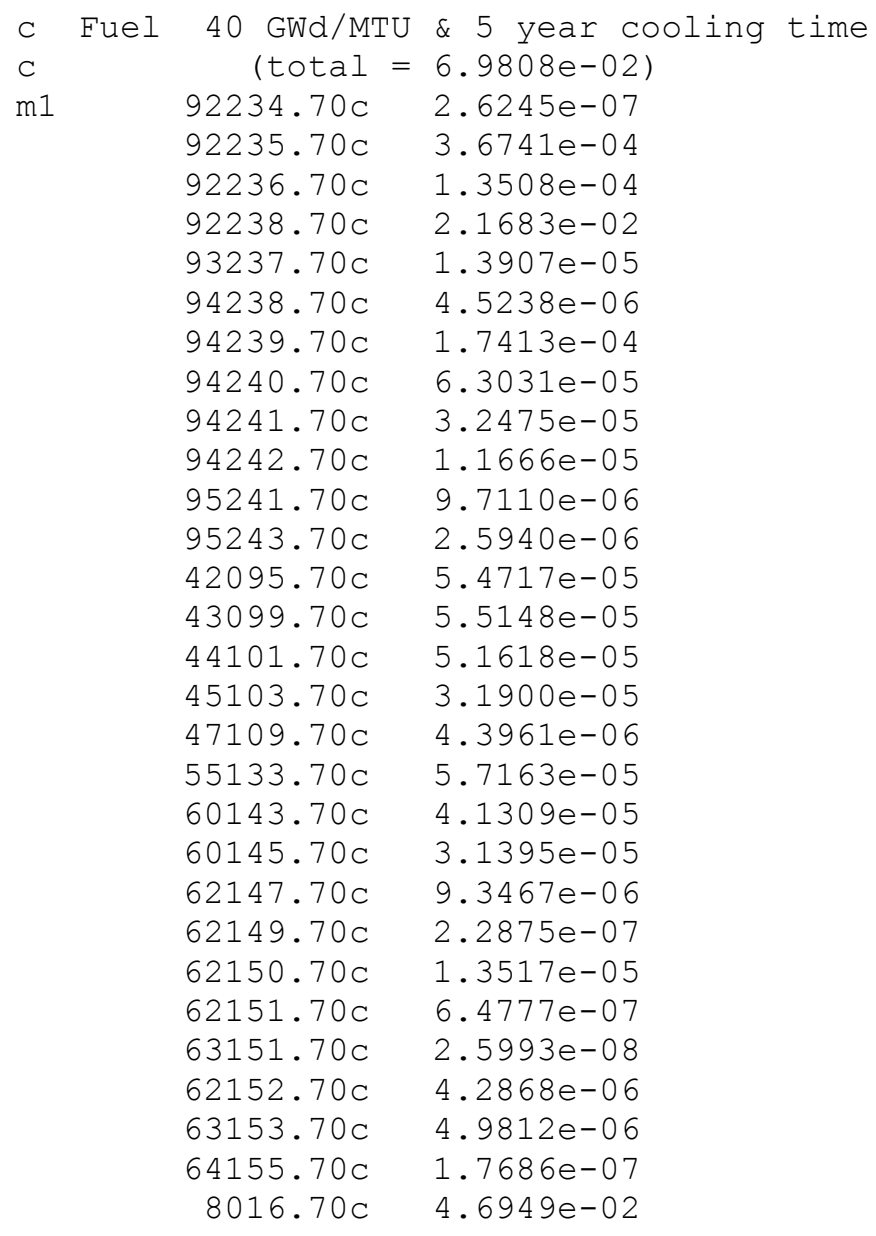


Composition input for fuel burned to $\mathbf{4 0} \mathrm{GWd} / \mathrm{MTU}$, following a 40 -year cooling time.

The total number density in cell 1 is changed to $6.9811 \mathrm{e}-02$

Replace composition $\mathrm{m} 1$ provided in the above GBC-32 input file.

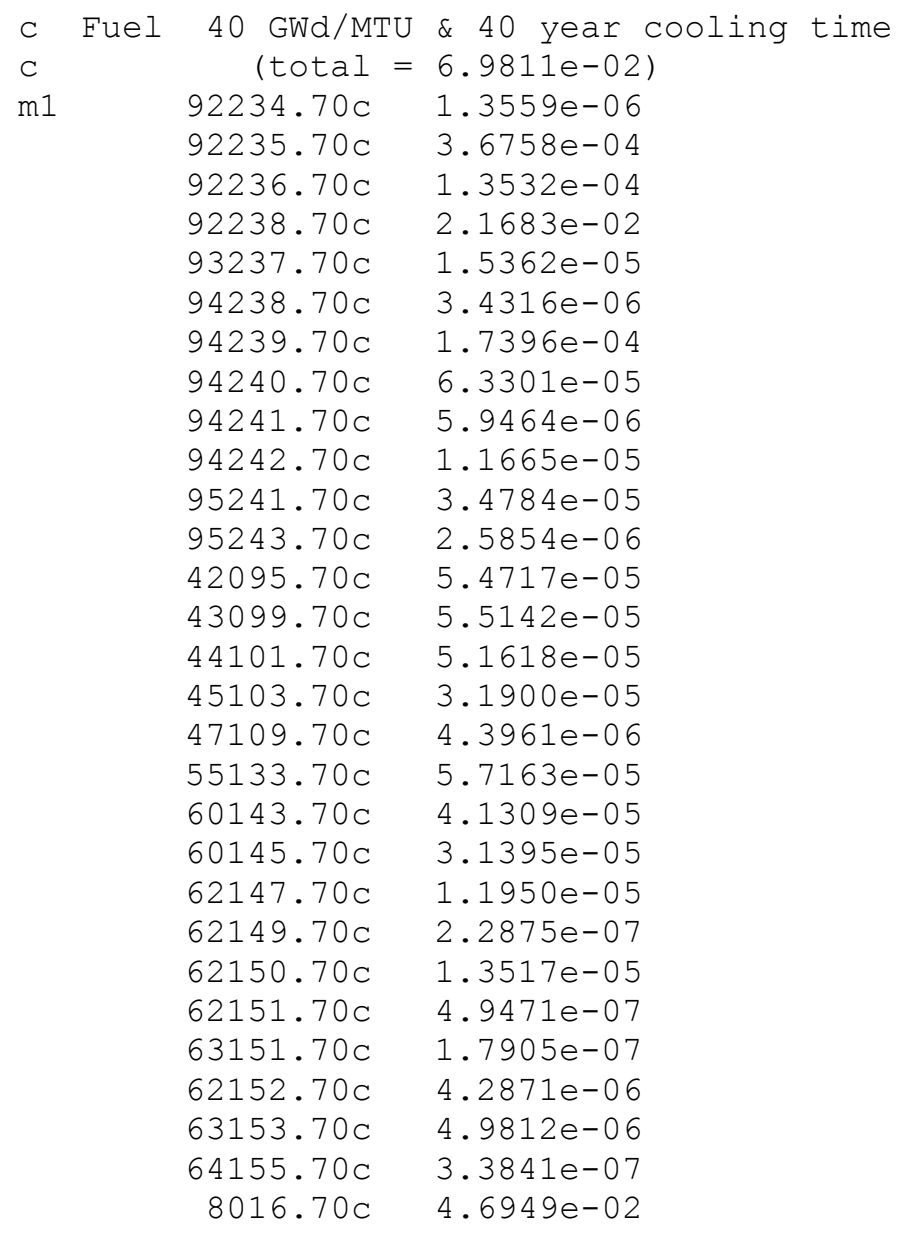




\section{APPENDIX C. DETAILED FP\&MA WORTH RESULTS FOR EACH CODE AND NUCLEAR DATA COMBINATION}

This appendix provides detailed fission products and minor actinides (FP\&MA) worth results for each code and nuclear data combination. Results for SCALE 6.1 using the ENDF/B-VII 238 group library are provided in Table 3.1.

Table C.1. FP\&MA worths using SCALE 6.1 and ENDF/B-VII continuous-energy data

\begin{tabular}{|c|c|c|c|c|}
\hline \multirow{2}{*}{$\begin{array}{c}\text { Initial enrichment and } \\
\text { final burnup } \\
\begin{array}{c}\text { Cooling time } \\
\text { (years) }\end{array}\end{array}$} & \multicolumn{2}{|c|}{$3.1 \mathrm{wt} \%$ and $20 \mathrm{GWd} / \mathrm{MTU}$} & \multicolumn{2}{|c|}{4.7 wt $\%$ and $40 \mathrm{GWd} / \mathrm{MTU}$} \\
\hline & 5 & 40 & 5 & 40 \\
\hline & \multicolumn{4}{|c|}{$\begin{array}{c}\text { FP\&MA worths } \\
(\Delta \mathbf{k})^{a}\end{array}$} \\
\hline All FP\&MA & -0.06720 & -0.06945 & -0.10149 & -0.10399 \\
\hline All MA & -0.00609 & -0.00657 & -0.01120 & -0.01096 \\
\hline All FP & -0.06018 & -0.06255 & -0.08745 & -0.09037 \\
\hline${ }^{236} U$ & -0.00367 & -0.00390 & -0.00544 & -0.00512 \\
\hline${ }^{237} \mathrm{~Np}$ & -0.00209 & -0.00249 & -0.00435 & -0.00472 \\
\hline${ }^{243} \mathrm{Am}$ & -0.00021 & -0.00058 & -0.00094 & -0.00099 \\
\hline${ }^{95} \mathrm{Mo}$ & -0.00120 & -0.00135 & -0.00160 & -0.00170 \\
\hline${ }^{99} \mathrm{Tc}$ & -0.00231 & -0.00270 & -0.00384 & -0.00365 \\
\hline${ }^{101} \mathrm{Ru}$ & -0.00073 & -0.00121 & -0.00146 & -0.00134 \\
\hline${ }^{103} \mathrm{Rh}$ & -0.00695 & -0.00707 & -0.01049 & -0.00968 \\
\hline${ }^{109} \mathrm{Ag}$ & -0.00074 & -0.00123 & -0.00145 & -0.00128 \\
\hline${ }^{133} \mathrm{Cs}$ & -0.00334 & -0.00352 & -0.00521 & -0.00497 \\
\hline${ }^{143} \mathrm{Nd}$ & -0.00866 & -0.00898 & -0.01299 & -0.01249 \\
\hline${ }^{145} \mathrm{Nd}$ & -0.00165 & -0.00207 & -0.00279 & -0.00293 \\
\hline${ }^{147} \mathrm{Sm}$ & -0.00128 & -0.00212 & -0.00199 & -0.00239 \\
\hline${ }^{149} \mathrm{Sm}$ & -0.01555 & -0.01532 & -0.01597 & -0.01532 \\
\hline${ }^{150} \mathrm{Sm}$ & -0.00071 & -0.00114 & -0.00128 & -0.00123 \\
\hline${ }^{151} \mathrm{Sm}$ & -0.00584 & -0.00465 & -0.00701 & -0.00522 \\
\hline${ }^{152} \mathrm{Sm}$ & -0.00198 & -0.00256 & -0.00279 & -0.00284 \\
\hline${ }^{151} \mathrm{Eu}$ & -0.00004 & -0.00156 & 0.00002 & -0.00150 \\
\hline${ }^{153} \mathrm{Eu}$ & -0.00165 & -0.00171 & -0.00270 & -0.00288 \\
\hline${ }^{155} \mathrm{Gd}$ & -0.00357 & -0.00712 & -0.00667 & -0.01294 \\
\hline
\end{tabular}

${ }^{a}$ Monte Carlo uncertainty is $0.00014 \Delta \mathrm{k}$ for FP\&MA worths. 
Table C.2. FP\&MA worths using SCALE 6.1 and ENDF/B-VI 238 energy group data

\begin{tabular}{|c|c|c|c|c|}
\hline \multirow{2}{*}{$\begin{array}{c}\text { Initial enrichment and } \\
\text { final burnup } \\
\begin{array}{c}\text { Cooling time } \\
\text { (years) }\end{array}\end{array}$} & \multicolumn{2}{|c|}{$3.1 \mathrm{wt} \%$ and $20 \mathrm{GWd} / \mathrm{MTU}$} & \multicolumn{2}{|c|}{4.7 wt $\%$ and $40 \mathrm{GWd} / \mathrm{MTU}$} \\
\hline & 5 & 40 & 5 & 40 \\
\hline & \multicolumn{4}{|c|}{$\begin{array}{c}\text { FP\&MA worths } \\
(\Delta \mathbf{k})^{a}\end{array}$} \\
\hline All FP\&MA & -0.06755 & -0.06888 & -0.10152 & -0.10374 \\
\hline All MA & -0.00673 & -0.00618 & -0.01158 & -0.01087 \\
\hline All FP & -0.06022 & -0.06198 & -0.08743 & -0.09012 \\
\hline${ }^{236} U$ & -0.00396 & -0.00345 & -0.00570 & -0.00507 \\
\hline${ }^{237} \mathrm{~Np}$ & -0.00225 & -0.00238 & -0.00471 & -0.00471 \\
\hline${ }^{243} \mathrm{Am}$ & -0.00023 & -0.00007 & -0.00098 & -0.00080 \\
\hline${ }^{95} \mathrm{Mo}$ & -0.00132 & -0.00100 & -0.00179 & -0.00164 \\
\hline${ }^{99} \mathrm{Tc}$ & -0.00211 & -0.00198 & -0.00336 & -0.00321 \\
\hline${ }^{101} \mathrm{Ru}$ & -0.00069 & -0.00078 & -0.00141 & -0.00111 \\
\hline${ }^{103} \mathrm{Rh}$ & -0.00704 & -0.00658 & -0.01029 & -0.00928 \\
\hline${ }^{109} \mathrm{Ag}$ & -0.00109 & -0.00071 & -0.00154 & -0.00157 \\
\hline${ }^{133} \mathrm{Cs}$ & -0.00341 & -0.00296 & -0.00531 & -0.00487 \\
\hline${ }^{143} \mathrm{Nd}$ & -0.00912 & -0.00870 & -0.01319 & -0.01229 \\
\hline${ }^{145} \mathrm{Nd}$ & -0.00183 & -0.00161 & -0.00271 & -0.00270 \\
\hline${ }^{147} \mathrm{Sm}$ & -0.00143 & -0.00155 & -0.00185 & -0.00252 \\
\hline${ }^{149} \mathrm{Sm}$ & -0.01655 & -0.01574 & -0.01688 & -0.01619 \\
\hline${ }^{150} \mathrm{Sm}$ & -0.00099 & -0.00050 & -0.00148 & -0.00126 \\
\hline${ }^{151} \mathrm{Sm}$ & -0.00629 & -0.00419 & -0.00723 & -0.00534 \\
\hline${ }^{152} \mathrm{Sm}$ & -0.00222 & -0.00190 & -0.00309 & -0.00272 \\
\hline${ }^{151} \mathrm{Eu}$ & -0.00024 & -0.00105 & -0.00018 & -0.00134 \\
\hline${ }^{153} \mathrm{Eu}$ & -0.00170 & -0.00123 & -0.00286 & -0.00270 \\
\hline${ }^{155} \mathrm{Gd}$ & -0.00372 & -0.00650 & -0.00730 & -0.01302 \\
\hline
\end{tabular}

${ }^{a}$ Monte Carlo uncertainty is $0.00014 \Delta \mathrm{k}$ for FP\&MA worths. 
Table C.3. FP\&MA worths using SCALE 6.1 and ENDF/B-V 238 energy group data

\begin{tabular}{|c|c|c|c|c|}
\hline \multirow{2}{*}{$\begin{array}{c}\text { Initial enrichment and } \\
\text { final burnup } \\
\begin{array}{c}\text { Cooling time } \\
\text { (years) }\end{array}\end{array}$} & \multicolumn{2}{|c|}{$3.1 \mathrm{wt} \%$ and $20 \mathrm{GWd} / \mathrm{MTU}$} & \multicolumn{2}{|c|}{4.7 wt $\%$ and $40 \mathrm{GWd} / \mathrm{MTU}$} \\
\hline & 5 & 40 & 5 & 40 \\
\hline & \multicolumn{4}{|c|}{$\begin{array}{c}\text { FP\&MA worths } \\
(\Delta \mathbf{k})^{a}\end{array}$} \\
\hline All FP\&MA & -0.06585 & -0.06808 & -0.09966 & -0.10229 \\
\hline All MA & -0.00615 & -0.00632 & -0.01159 & -0.01109 \\
\hline All FP & -0.05856 & -0.06113 & -0.08544 & -0.08835 \\
\hline${ }^{236} \mathrm{U}$ & -0.00349 & -0.00375 & -0.00545 & -0.00518 \\
\hline${ }^{237} \mathrm{~Np}$ & -0.00197 & -0.00247 & -0.00484 & -0.00496 \\
\hline${ }^{243} \mathrm{Am}$ & -0.00016 & -0.00049 & -0.00110 & -0.00111 \\
\hline${ }^{95} \mathrm{Mo}$ & -0.00114 & -0.00116 & -0.00182 & -0.00176 \\
\hline${ }^{99} \mathrm{Tc}$ & -0.00204 & -0.00221 & -0.00376 & -0.00350 \\
\hline${ }^{101} \mathrm{Ru}$ & -0.00056 & -0.00077 & -0.00118 & -0.00137 \\
\hline${ }^{103} \mathrm{Rh}$ & -0.00678 & -0.00668 & -0.01041 & -0.00959 \\
\hline${ }^{109} \mathrm{Ag}$ & -0.00067 & -0.00108 & -0.00171 & -0.00138 \\
\hline${ }^{133} \mathrm{Cs}$ & -0.00272 & -0.00299 & -0.00463 & -0.00450 \\
\hline${ }^{143} \mathrm{Nd}$ & -0.00885 & -0.00886 & -0.01305 & -0.01268 \\
\hline${ }^{145} \mathrm{Nd}$ & -0.00149 & -0.00170 & -0.00269 & -0.00257 \\
\hline${ }^{147} \mathrm{Sm}$ & -0.00134 & -0.00186 & -0.00210 & -0.00270 \\
\hline${ }^{149} \mathrm{Sm}$ & -0.01547 & -0.01538 & -0.01634 & -0.01567 \\
\hline${ }^{150} \mathrm{Sm}$ & -0.00077 & -0.00089 & -0.00173 & -0.00159 \\
\hline${ }^{151} \mathrm{Sm}$ & -0.00552 & -0.00445 & -0.00700 & -0.00537 \\
\hline${ }^{152} \mathrm{Sm}$ & -0.00186 & -0.00215 & -0.00323 & -0.00305 \\
\hline${ }^{151} \mathrm{Eu}$ & 0.00019 & -0.00146 & -0.00026 & -0.00176 \\
\hline${ }^{153} \mathrm{Eu}$ & -0.00118 & -0.00145 & -0.00290 & -0.00271 \\
\hline${ }^{155} \mathrm{Gd}$ & -0.00316 & -0.00662 & -0.00709 & -0.01287 \\
\hline
\end{tabular}

${ }^{a}$ Monte Carlo uncertainty is $0.00014 \Delta \mathrm{k}$ for FP\&MA worths. 
Table C.4. FP\&MA worths using SCALE 6.1 and ENDF/B-V 44 energy group data

\begin{tabular}{|c|c|c|c|c|}
\hline \multirow{2}{*}{$\begin{array}{c}\text { Initial enrichment and } \\
\text { final burnup } \\
\begin{array}{c}\text { Cooling time } \\
\text { (years) }\end{array}\end{array}$} & \multicolumn{2}{|c|}{$3.1 \mathrm{wt} \%$ and $20 \mathrm{GWd} / \mathrm{MTU}$} & \multicolumn{2}{|c|}{4.7 wt $\%$ and $40 \mathrm{GWd} / \mathrm{MTU}$} \\
\hline & 5 & 40 & 5 & 40 \\
\hline & \multicolumn{4}{|c|}{$\begin{array}{c}\text { FP\&MA worths } \\
(\Delta \mathbf{k})^{a}\end{array}$} \\
\hline All FP\&MA & -0.06635 & -0.06836 & -0.10000 & -0.10288 \\
\hline All MA & -0.00622 & -0.00639 & -0.01186 & -0.01126 \\
\hline All FP & -0.05915 & -0.06132 & -0.08593 & -0.08896 \\
\hline${ }^{236} \mathrm{U}$ & -0.00402 & -0.00404 & -0.00606 & -0.00542 \\
\hline${ }^{237} \mathrm{~Np}$ & -0.00221 & -0.00249 & -0.00489 & -0.00480 \\
\hline${ }^{243} \mathrm{Am}$ & -0.00015 & -0.00037 & -0.00113 & -0.00091 \\
\hline${ }^{95} \mathrm{Mo}$ & -0.00131 & -0.00131 & -0.00204 & -0.00158 \\
\hline${ }^{99} \mathrm{Tc}$ & -0.00276 & -0.00253 & -0.00420 & -0.00379 \\
\hline${ }^{101} \mathrm{Ru}$ & -0.00074 & -0.00089 & -0.00146 & -0.00118 \\
\hline${ }^{103} \mathrm{Rh}$ & -0.00699 & -0.00674 & -0.01041 & -0.00923 \\
\hline${ }^{109} \mathrm{Ag}$ & -0.00084 & -0.00117 & -0.00166 & -0.00137 \\
\hline${ }^{133} \mathrm{Cs}$ & -0.00316 & -0.00317 & -0.00505 & -0.00488 \\
\hline${ }^{143} \mathrm{Nd}$ & -0.00897 & -0.00882 & -0.01332 & -0.01286 \\
\hline${ }^{145} \mathrm{Nd}$ & -0.00154 & -0.00186 & -0.00283 & -0.00255 \\
\hline${ }^{147} \mathrm{Sm}$ & -0.00144 & -0.00161 & -0.00215 & -0.00247 \\
\hline${ }^{149} \mathrm{Sm}$ & -0.01571 & -0.01557 & -0.01668 & -0.01569 \\
\hline${ }^{150} \mathrm{Sm}$ & -0.00133 & -0.00139 & -0.00209 & -0.00206 \\
\hline${ }^{151} \mathrm{Sm}$ & -0.00581 & -0.00427 & -0.00705 & -0.00517 \\
\hline${ }^{152} \mathrm{Sm}$ & -0.00205 & -0.00187 & -0.00309 & -0.00256 \\
\hline${ }^{151} \mathrm{Eu}$ & -0.00033 & -0.00144 & -0.00038 & -0.00128 \\
\hline${ }^{153} \mathrm{Eu}$ & -0.00143 & -0.00145 & -0.00285 & -0.00264 \\
\hline${ }^{155} \mathrm{Gd}$ & -0.00359 & -0.00687 & -0.00696 & -0.01301 \\
\hline
\end{tabular}

${ }^{a}$ Monte Carlo uncertainty is $0.00014 \Delta \mathrm{k}$ for FP\&MA worths. 
Table C.5. FP\&MA worths using MCNP5 (version 1.60) and ENDF/B-VII data

\begin{tabular}{|c|c|c|c|c|}
\hline \multirow{2}{*}{$\begin{array}{c}\begin{array}{c}\text { Initial enrichment and } \\
\text { final burnup }\end{array} \\
\begin{array}{c}\text { Cooling time } \\
\text { (years) }\end{array} \\
\end{array}$} & \multicolumn{2}{|c|}{$3.1 \mathrm{wt} \%$ and $20 \mathrm{GWd} / \mathrm{MTU}$} & \multicolumn{2}{|c|}{$4.7 \mathrm{wt} \%$ and $40 \mathrm{GWd} / \mathrm{MTU}$} \\
\hline & 5 & 40 & 5 & 40 \\
\hline & \multicolumn{4}{|c|}{$\begin{array}{c}\text { FP\&MA worths } \\
(\Delta \mathbf{k})^{a}\end{array}$} \\
\hline All FP\&MA & -0.06748 & -0.06969 & -0.10213 & -0.10456 \\
\hline All MA & -0.00618 & -0.00619 & -0.01127 & -0.01073 \\
\hline All FP & -0.06042 & -0.06244 & -0.08820 & -0.09096 \\
\hline${ }^{236} \mathrm{U}(92236.70 \mathrm{c})$ & -0.00376 & -0.00374 & -0.00580 & -0.00523 \\
\hline${ }^{237} \mathrm{~Np}(93237.70 \mathrm{c})$ & -0.00216 & -0.00241 & -0.00443 & -0.00460 \\
\hline${ }^{243} \mathrm{Am}(95243.70 \mathrm{c})$ & -0.00002 & -0.00038 & -0.00117 & -0.00104 \\
\hline${ }^{95} \mathrm{Mo}(42095.70 \mathrm{c})$ & -0.00101 & -0.00105 & -0.00176 & -0.00164 \\
\hline${ }^{99} \mathrm{Tc}(43099.70 \mathrm{c})$ & -0.00256 & -0.00259 & -0.00388 & -0.00365 \\
\hline${ }^{101} \mathrm{Ru}(44101.70 \mathrm{c})$ & -0.00076 & -0.00093 & -0.00135 & -0.00142 \\
\hline${ }^{103} \operatorname{Rh}(45103.70 \mathrm{c})$ & -0.00688 & -0.00675 & -0.01026 & -0.00944 \\
\hline${ }^{109} \mathrm{Ag}(47109.70 \mathrm{c})$ & -0.00087 & -0.00080 & -0.00160 & -0.00139 \\
\hline${ }^{133} \mathrm{Cs}(55133.70 \mathrm{c})$ & -0.00334 & -0.00328 & -0.00546 & -0.00511 \\
\hline${ }^{143} \mathrm{Nd}(60143.70 \mathrm{c})$ & -0.00877 & -0.00887 & -0.01331 & -0.01259 \\
\hline${ }^{145} \mathrm{Nd}(60145.70 \mathrm{c})$ & -0.00176 & -0.00187 & -0.00282 & -0.00276 \\
\hline${ }^{147} \mathrm{Sm}(62147.70 \mathrm{c})$ & -0.00137 & -0.00191 & -0.00214 & -0.00240 \\
\hline${ }^{149} \mathrm{Sm}(62149.70 \mathrm{c})$ & -0.01570 & -0.01530 & -0.01637 & -0.01564 \\
\hline${ }^{150} \mathrm{Sm}(62150.70 \mathrm{c})$ & -0.00081 & -0.00097 & -0.00151 & -0.00136 \\
\hline${ }^{151} \mathrm{Sm}(62151.70 \mathrm{c})$ & -0.00612 & -0.00461 & -0.00734 & -0.00555 \\
\hline${ }^{152} \mathrm{Sm}(62152.70 \mathrm{c})$ & -0.00211 & -0.00220 & -0.00298 & -0.00285 \\
\hline${ }^{151} \mathrm{Eu}(63151.70 \mathrm{c})$ & -0.00015 & -0.00142 & -0.00020 & -0.00158 \\
\hline${ }^{153} \mathrm{Eu}(63153.70 \mathrm{c})$ & -0.00167 & -0.00156 & -0.00270 & -0.00271 \\
\hline${ }^{155} \mathrm{Gd}(64155.70 \mathrm{c})$ & -0.00354 & -0.00689 & -0.00723 & -0.01301 \\
\hline
\end{tabular}

Note: MCNP = Monte Carlo N-Particle.

${ }^{a}$ Monte Carlo uncertainty is less than $0.00012 \Delta \mathrm{k}$ for FP\&MA worths. 
Table C.6. FP\&MA worths using MCNP5 (version 1.60) and ENDF/B-VI data

\begin{tabular}{|c|c|c|c|c|}
\hline \multirow{2}{*}{$\begin{array}{c}\begin{array}{c}\text { Initial enrichment and } \\
\text { final burnup }\end{array} \\
\begin{array}{c}\text { Cooling time } \\
\text { (years) }\end{array} \\
\end{array}$} & \multicolumn{2}{|c|}{$3.1 \mathrm{wt} \%$ and $20 \mathrm{GWd} / \mathrm{MTU}$} & \multicolumn{2}{|c|}{$4.7 \mathrm{wt} \%$ and $40 \mathrm{GWd} / \mathrm{MTU}$} \\
\hline & 5 & 40 & 5 & 40 \\
\hline & \multicolumn{4}{|c|}{$\begin{array}{l}\text { FP\&MA worths } \\
(\Delta \mathbf{k})^{a}\end{array}$} \\
\hline All FP\&MA & -0.04529 & -0.04918 & -0.06910 & -0.07487 \\
\hline All MA & -0.00659 & -0.00616 & -0.01194 & -0.01158 \\
\hline All FP & -0.03797 & -0.04222 & -0.05474 & -0.06139 \\
\hline${ }^{236} \cup(92236.69 c)$ & -0.00403 & -0.00400 & -0.00611 & -0.00516 \\
\hline${ }^{237} \mathrm{~Np}(93237.69 \mathrm{c})$ & -0.00214 & -0.00242 & -0.00486 & -0.00500 \\
\hline${ }^{243} \mathrm{Am}(95243.69 \mathrm{c})$ & -0.00024 & -0.00026 & -0.00087 & -0.00079 \\
\hline${ }^{95} \mathrm{Mo}$ & $b$ & $b$ & $b$ & $b$ \\
\hline${ }^{99} \mathrm{Tc}(43099.66 \mathrm{c})$ & -0.00236 & -0.00213 & -0.00361 & -0.00328 \\
\hline${ }^{101} \mathrm{Ru}$ & $b$ & $b$ & $b$ & $b$ \\
\hline${ }^{103} \mathrm{Rh}(45103.66 \mathrm{c})$ & -0.00728 & -0.00673 & -0.01080 & -0.01007 \\
\hline${ }^{109} \mathrm{Ag}(47109.66 \mathrm{c})$ & -0.00097 & -0.00031 & -0.00144 & -0.00132 \\
\hline${ }^{133} \mathrm{Cs}(55133.66 \mathrm{c})$ & -0.00309 & -0.00326 & -0.00540 & -0.00475 \\
\hline${ }^{143} \mathrm{Nd}$ & $b$ & $b$ & $b$ & $b$ \\
\hline${ }^{145} \mathrm{Nd}$ & $b$ & $b$ & $b$ & $b$ \\
\hline${ }^{147} \mathrm{Sm}(62147.66 \mathrm{c})$ & -0.00142 & -0.00183 & -0.00169 & -0.00240 \\
\hline${ }^{149} \mathrm{Sm}(62149.66 \mathrm{c})$ & -0.01671 & -0.01582 & -0.01800 & -0.01679 \\
\hline${ }^{150} \mathrm{Sm}$ & $b$ & $b$ & $b$ & $b$ \\
\hline${ }^{151} \mathrm{Sm}$ & $b$ & $b$ & $b$ & $b$ \\
\hline${ }^{152} \mathrm{Sm}$ & $b$ & $b$ & $b$ & $b$ \\
\hline${ }^{151} \mathrm{Eu}(63151.66 \mathrm{c})$ & -0.00041 & -0.00102 & -0.00027 & -0.00123 \\
\hline${ }^{153} \mathrm{Eu}(63153.66 \mathrm{c})$ & -0.00149 & -0.00134 & -0.00292 & -0.00271 \\
\hline${ }^{155} \mathrm{Gd}(64155.66 \mathrm{c})$ & -0.00381 & -0.00699 & -0.00771 & -0.01424 \\
\hline
\end{tabular}

Note: MCNP = Monte Carlo N-Particle.

${ }^{a}$ Monte Carlo uncertainty is less than $0.00014 \Delta \mathrm{k}$ for FP\&MA worths.

${ }^{b}{ }^{95} \mathrm{Mo},{ }^{101} \mathrm{Ru},{ }^{143} \mathrm{Nd},{ }^{145} \mathrm{Nd},{ }^{150} \mathrm{Sm},{ }^{151} \mathrm{Sm}$, and ${ }^{152} \mathrm{Sm}$ excluded because ENDF/B-VI data for these nuclides was not distributed with MCNP5 (v1.60). 
Table C.7. FP\&MA worths using MCNP5 (version 1.60) and ENDF/B-V data

\begin{tabular}{|c|c|c|c|c|}
\hline \multirow{2}{*}{$\begin{array}{c}\begin{array}{c}\text { Initial enrichment and } \\
\text { final burnup }\end{array} \\
\begin{array}{c}\text { Cooling time } \\
\text { (years) }\end{array} \\
\end{array}$} & \multicolumn{2}{|c|}{$3.1 \mathrm{wt} \%$ and $20 \mathrm{GWd} / \mathrm{MTU}$} & \multicolumn{2}{|c|}{$4.7 \mathrm{wt} \%$ and $40 \mathrm{GWd} / \mathrm{MTU}$} \\
\hline & 5 & 40 & 5 & 40 \\
\hline & \multicolumn{4}{|c|}{$\begin{array}{c}\text { FP\&MA worths } \\
(\Delta \mathbf{k})^{a}\end{array}$} \\
\hline All FP\&MA & -0.06688 & -0.06913 & -0.10154 & -0.10402 \\
\hline All MA & -0.00678 & -0.00696 & -0.01303 & -0.01238 \\
\hline All FP & -0.05922 & -0.06133 & -0.08593 & -0.08895 \\
\hline${ }^{236} \mathrm{U}(92236.51 \mathrm{c})$ & -0.00452 & -0.00428 & -0.00698 & -0.00627 \\
\hline${ }^{237} \mathrm{~Np}(93237.55 \mathrm{c})$ & -0.00209 & -0.00270 & -0.00485 & -0.00492 \\
\hline${ }^{243} \mathrm{Am}(95243.51 \mathrm{c})$ & -0.00018 & -0.00046 & -0.00122 & -0.00091 \\
\hline${ }^{95} \mathrm{Mo}(42095.50 \mathrm{c})$ & -0.00095 & -0.00130 & -0.00215 & -0.00155 \\
\hline${ }^{99} \mathrm{Tc}(43099.50 \mathrm{c})$ & -0.00198 & -0.00233 & -0.00370 & -0.00339 \\
\hline${ }^{101} \mathrm{Ru}(44101.50 \mathrm{c})$ & -0.00051 & -0.00072 & -0.00129 & -0.00130 \\
\hline${ }^{103} \operatorname{Rh}(45103.50 \mathrm{c})$ & -0.00702 & -0.00692 & -0.01042 & -0.00939 \\
\hline${ }^{109} \mathrm{Ag}(47109.50 \mathrm{c})$ & -0.00057 & -0.00096 & -0.00152 & -0.00171 \\
\hline${ }^{133} \mathrm{Cs}(55133.55 \mathrm{c})$ & -0.00295 & -0.00312 & -0.00513 & -0.00496 \\
\hline${ }^{143} \mathrm{Nd}(60143.50 \mathrm{c})$ & -0.00891 & -0.00897 & -0.01318 & -0.01253 \\
\hline${ }^{145} \mathrm{Nd}(60145.50 \mathrm{c})$ & -0.00143 & -0.00146 & -0.00267 & -0.00265 \\
\hline${ }^{147} \mathrm{Sm}(62147.50 \mathrm{c})$ & -0.00120 & -0.00162 & -0.00213 & -0.00241 \\
\hline${ }^{149} \mathrm{Sm}(62149.50 \mathrm{c})$ & -0.01580 & -0.01557 & -0.01623 & -0.01588 \\
\hline${ }^{150} \mathrm{Sm}(62150.50 \mathrm{c})$ & -0.00092 & -0.00093 & -0.00160 & -0.00122 \\
\hline${ }^{151} \mathrm{Sm}(62151.50 \mathrm{c})$ & -0.00532 & -0.00436 & -0.00688 & -0.00502 \\
\hline${ }^{152} \mathrm{Sm}(62152.50 \mathrm{c})$ & -0.00201 & -0.00218 & -0.00317 & -0.00311 \\
\hline${ }^{151} \mathrm{Eu}(63151.55 \mathrm{c})$ & -0.00011 & -0.00120 & -0.00022 & -0.00142 \\
\hline${ }^{153} \mathrm{Eu}(63153.55 \mathrm{c})$ & -0.00128 & -0.00141 & -0.00263 & -0.00261 \\
\hline${ }^{155} \mathrm{Gd}(64155.50 \mathrm{c})$ & -0.00340 & -0.00672 & -0.00709 & -0.01304 \\
\hline
\end{tabular}

Note: MCNP = Monte Carlo N-Particle.

${ }^{a}$ Monte Carlo uncertainty is less than $0.00013 \Delta \mathrm{k}$ for FP\&MA worths. 
Table C.8. FP\&MA worths using MCNP6 (new release) and ENDF/B-V data

\begin{tabular}{|c|c|c|c|c|}
\hline \multirow{2}{*}{$\begin{array}{c}\begin{array}{c}\text { Initial enrichment and } \\
\text { final burnup }\end{array} \\
\begin{array}{c}\text { Cooling time } \\
\text { (years) }\end{array} \\
\end{array}$} & \multicolumn{2}{|c|}{$3.1 \mathrm{wt} \%$ and $20 \mathrm{GWd} / \mathrm{MTU}$} & \multicolumn{2}{|c|}{$4.7 \mathrm{wt} \%$ and $40 \mathrm{GWd} / \mathrm{MTU}$} \\
\hline & 5 & 40 & 5 & 40 \\
\hline & \multicolumn{4}{|c|}{$\begin{array}{c}\text { FP\&MA worths } \\
(\Delta \mathbf{k})^{a}\end{array}$} \\
\hline All FP\&MA & -0.06705 & -0.06906 & -0.10136 & -0.10395 \\
\hline All MA & -0.0069 & -0.00673 & -0.01271 & -0.01233 \\
\hline All FP & -0.05915 & -0.06108 & -0.08581 & -0.08898 \\
\hline${ }^{236} \mathrm{U}(92236.51 \mathrm{c})$ & -0.00458 & -0.00418 & -0.00697 & -0.0062 \\
\hline${ }^{237} \mathrm{~Np}(93237.55 \mathrm{c})$ & -0.00211 & -0.00233 & -0.00477 & -0.0051 \\
\hline${ }^{243} \mathrm{Am}(95243.51 \mathrm{c})$ & -0.00016 & -0.00028 & -0.00114 & -0.00096 \\
\hline${ }^{95} \mathrm{Mo}(42095.50 \mathrm{c})$ & -0.00106 & -0.00107 & -0.0019 & -0.00184 \\
\hline${ }^{99} \mathrm{Tc}(43099.50 \mathrm{c})$ & -0.0023 & -0.00207 & -0.00356 & -0.00342 \\
\hline${ }^{101} \mathrm{Ru}(44101.50 \mathrm{c})$ & -0.00075 & -0.0005 & -0.00113 & -0.00119 \\
\hline${ }^{103} \operatorname{Rh}(45103.50 \mathrm{c})$ & -0.00701 & -0.0066 & -0.01033 & -0.00942 \\
\hline${ }^{109} \mathrm{Ag}(47109.50 \mathrm{c})$ & -0.00088 & -0.00076 & -0.0013 & -0.00139 \\
\hline${ }^{133} \mathrm{Cs}(55133.55 \mathrm{c})$ & -0.00315 & -0.00288 & -0.00512 & -0.00479 \\
\hline${ }^{143} \mathrm{Nd}(60143.50 \mathrm{c})$ & -0.00885 & -0.00847 & -0.0132 & -0.01262 \\
\hline${ }^{145} \mathrm{Nd}(60145.50 \mathrm{c})$ & -0.0017 & -0.00147 & -0.00259 & -0.00247 \\
\hline${ }^{147} \mathrm{Sm}(62147.50 \mathrm{c})$ & -0.00145 & -0.00162 & -0.00203 & -0.00252 \\
\hline${ }^{149} \mathrm{Sm}(62149.50 \mathrm{c})$ & -0.01593 & -0.01532 & -0.01642 & -0.01571 \\
\hline${ }^{150} \mathrm{Sm}(62150.50 c)$ & -0.00063 & -0.00077 & -0.0015 & -0.00144 \\
\hline${ }^{151} \mathrm{Sm}(62151.50 \mathrm{c})$ & -0.00552 & -0.00395 & -0.00686 & -0.00499 \\
\hline${ }^{152} \mathrm{Sm}(62152.50 c)$ & -0.00227 & -0.00211 & -0.00309 & -0.00283 \\
\hline${ }^{151} \mathrm{Eu}(63151.55 \mathrm{c})$ & -0.00008 & -0.00109 & -0.0002 & -0.00149 \\
\hline${ }^{153} \mathrm{Eu}(63153.55 \mathrm{c})$ & -0.00142 & -0.00129 & -0.00288 & -0.0025 \\
\hline${ }^{155} \mathrm{Gd}(64155.50 \mathrm{c})$ & -0.00357 & -0.00661 & -0.00706 & -0.01316 \\
\hline
\end{tabular}

Note: MCNP = Monte Carlo N-Particle.

${ }^{a}$ Monte Carlo uncertainty is less than $0.00013 \Delta \mathrm{k}$ for FP\&MA worths. 
Table C.9. FP\&MA worths using MCNP6 (new release) and ENDF/B-VI data

\begin{tabular}{|c|c|c|c|c|}
\hline \multirow{2}{*}{$\begin{array}{c}\text { Initial enrichment and } \\
\text { final burnup } \\
\begin{array}{c}\text { Cooling time } \\
\text { (years) }\end{array}\end{array}$} & \multicolumn{2}{|c|}{$3.1 \mathrm{wt} \%$ and $20 \mathrm{GWd} / \mathrm{MTU}$} & \multicolumn{2}{|c|}{$4.7 \mathrm{wt} \%$ and $40 \mathrm{GWd} / \mathrm{MTU}$} \\
\hline & 5 & 40 & 5 & 40 \\
\hline & \multicolumn{4}{|c|}{$\begin{array}{c}\text { FP\&MA worths } \\
(\Delta \mathbf{k})^{a}\end{array}$} \\
\hline All FP\&MA & -0.04525 & -0.04908 & -0.0692 & -0.07511 \\
\hline All MA & -0.00658 & -0.00641 & -0.01215 & -0.0118 \\
\hline All FP & -0.03828 & -0.04205 & -0.05505 & -0.06144 \\
\hline${ }^{236} \cup(92236.69 c)$ & -0.00409 & -0.00375 & -0.00591 & -0.00552 \\
\hline${ }^{237} \mathrm{~Np}(93237.69 \mathrm{c})$ & -0.00225 & -0.0023 & -0.00495 & -0.00527 \\
\hline${ }^{243} \mathrm{Am}(95243.69 \mathrm{c})$ & -0.00007 & -0.00028 & -0.00101 & -0.00106 \\
\hline${ }^{99} \mathrm{Tc}(43099.66 \mathrm{c})$ & -0.00235 & -0.00206 & -0.00377 & -0.00352 \\
\hline${ }^{103} \operatorname{Rh}(45103.66 \mathrm{c})$ & -0.0072 & -0.00687 & -0.01072 & -0.01007 \\
\hline${ }^{109} \mathrm{Ag}(47109.66 \mathrm{c})$ & -0.00087 & -0.00076 & -0.00138 & -0.00145 \\
\hline${ }^{133} \mathrm{Cs}(55133.66 \mathrm{c})$ & -0.00305 & -0.0031 & -0.00521 & -0.0050 \\
\hline${ }^{147} \mathrm{Sm}(62147.66 \mathrm{c})$ & -0.00136 & -0.00174 & -0.00198 & -0.00264 \\
\hline${ }^{149} \mathrm{Sm}(62149.66 \mathrm{c})$ & -0.01680 & -0.01613 & -0.01775 & -0.01692 \\
\hline${ }^{151} \mathrm{Eu}(63151.66 \mathrm{c})$ & -0.00016 & -0.00117 & -0.00001 & -0.00154 \\
\hline${ }^{153} \mathrm{Eu}(63153.66 \mathrm{c})$ & -0.00152 & -0.00131 & -0.00291 & -0.00283 \\
\hline${ }^{155} \mathrm{Gd}(64155.66 \mathrm{c})$ & -0.00363 & -0.00707 & -0.00772 & -0.01431 \\
\hline
\end{tabular}

Note: MCNP = Monte Carlo N-Particle.

${ }^{a}$ Monte Carlo uncertainty is less than $0.00013 \Delta \mathrm{k}$ for FP\&MA worths. 
Table C.10. FP\&MA worths using MCNP6 (new release) and ENDF/B-VII data

\begin{tabular}{|c|c|c|c|c|}
\hline \multirow{2}{*}{$\begin{array}{c}\begin{array}{c}\text { Initial enrichment and } \\
\text { final burnup }\end{array} \\
\begin{array}{c}\text { Cooling time } \\
\text { (years) }\end{array} \\
\end{array}$} & \multicolumn{2}{|c|}{$3.1 \mathrm{wt} \%$ and $20 \mathrm{GWd} / \mathrm{MTU}$} & \multicolumn{2}{|c|}{$4.7 \mathrm{wt} \%$ and $40 \mathrm{GWd} / \mathrm{MTU}$} \\
\hline & 5 & 40 & 5 & 40 \\
\hline & \multicolumn{4}{|c|}{$\begin{array}{c}\text { FP\&MA worths } \\
(\Delta \mathbf{k})^{a}\end{array}$} \\
\hline All FP\&MA & -0.06762 & -0.06961 & -0.10222 & -0.1045 \\
\hline All MA & -0.00606 & -0.00608 & -0.01126 & -0.01089 \\
\hline All FP & -0.06053 & -0.06269 & -0.08838 & -0.09093 \\
\hline${ }^{236} \cup(92236.70 c)$ & -0.00393 & -0.00368 & -0.00579 & -0.00514 \\
\hline${ }^{237} \mathrm{~Np}(93237.70 \mathrm{c})$ & -0.0019 & -0.00232 & -0.00447 & -0.00448 \\
\hline${ }^{243} \mathrm{Am}(95243.70 \mathrm{c})$ & -0.00021 & -0.00032 & -0.0011 & -0.00081 \\
\hline${ }^{95} \mathrm{Mo}(42095.70 \mathrm{c})$ & -0.00115 & -0.00116 & -0.00204 & -0.0016 \\
\hline${ }^{99} \mathrm{Tc}(43099.70 \mathrm{c})$ & -0.00253 & -0.0025 & -0.00403 & -0.00351 \\
\hline${ }^{101} \mathrm{Ru}(44101.70 \mathrm{c})$ & -0.00063 & -0.00075 & -0.00152 & -0.0012 \\
\hline${ }^{103} \operatorname{Rh}(45103.70 \mathrm{c})$ & -0.00677 & -0.00664 & -0.01045 & -0.00929 \\
\hline${ }^{109} \mathrm{Ag}(47109.70 \mathrm{c})$ & -0.00084 & -0.00085 & -0.00182 & -0.0014 \\
\hline${ }^{133} \mathrm{Cs}(55133.70 \mathrm{c})$ & -0.00332 & -0.00323 & -0.00536 & -0.00481 \\
\hline${ }^{143} \mathrm{Nd}(60143.70 \mathrm{c})$ & -0.00888 & -0.00885 & -0.01331 & -0.0125 \\
\hline${ }^{145} \mathrm{Nd}(60145.70 \mathrm{c})$ & -0.0018 & -0.00166 & -0.00297 & -0.00255 \\
\hline${ }^{147} \mathrm{Sm}(62147.70 \mathrm{c})$ & -0.00143 & -0.00185 & -0.00192 & -0.00233 \\
\hline${ }^{149} \mathrm{Sm}(62149.70 \mathrm{c})$ & -0.01558 & -0.01531 & -0.01649 & -0.01559 \\
\hline${ }^{150} \mathrm{Sm}(62150.70 c)$ & -0.00078 & -0.0008 & -0.00164 & -0.00129 \\
\hline${ }^{151} \mathrm{Sm}(62151.70 \mathrm{c})$ & -0.00584 & -0.00431 & -0.00756 & -0.00514 \\
\hline${ }^{152} \mathrm{Sm}(62152.70 c)$ & -0.00211 & -0.00211 & -0.0033 & -0.00272 \\
\hline${ }^{151} \mathrm{Eu}(63151.70 \mathrm{c})$ & -0.00027 & -0.00142 & -0.00023 & -0.00142 \\
\hline${ }^{153} \mathrm{Eu}(63153.70 \mathrm{c})$ & -0.00152 & -0.00149 & -0.00294 & -0.00261 \\
\hline${ }^{155} \mathrm{Gd}(64155.70 \mathrm{c})$ & -0.00352 & -0.00681 & -0.00727 & -0.01304 \\
\hline
\end{tabular}

Note: MCNP = Monte Carlo N-Particle.

${ }^{a}$ Monte Carlo uncertainty is less than $0.00013 \Delta \mathrm{k}$ for FP\&MA worths. 
Table C.11. FP\&MA worths using MCNP6 (new release) and ENDF/B-VII.1 data

\begin{tabular}{|c|c|c|c|c|}
\hline \multirow{2}{*}{$\begin{array}{c}\begin{array}{c}\text { Initial enrichment and } \\
\text { final burnup }\end{array} \\
\begin{array}{c}\text { Cooling time } \\
\text { (years) }\end{array} \\
\end{array}$} & \multicolumn{2}{|c|}{$3.1 \mathrm{wt} \%$ and $20 \mathrm{GWd} / \mathrm{MTU}$} & \multicolumn{2}{|c|}{$4.7 \mathrm{wt} \%$ and $40 \mathrm{GWd} / \mathrm{MTU}$} \\
\hline & 5 & 40 & 5 & 40 \\
\hline & \multicolumn{4}{|c|}{$\begin{array}{c}\text { FP\&MA worths } \\
(\Delta \mathbf{k})^{a}\end{array}$} \\
\hline All FP\&MA & -0.06663 & -0.0684 & -0.10099 & -0.10268 \\
\hline All MA & -0.00629 & -0.00615 & -0.01182 & -0.01101 \\
\hline All FP & -0.05954 & -0.06127 & -0.08662 & -0.08883 \\
\hline${ }^{236} \cup(92236.80 c)$ & -0.00391 & -0.0037 & -0.00576 & -0.00503 \\
\hline${ }^{237} \mathrm{~Np}(93237.80 \mathrm{c})$ & -0.00208 & -0.00237 & -0.00456 & -0.00468 \\
\hline${ }^{243} \mathrm{Am}(95243.80 \mathrm{c})$ & -0.00022 & -0.00025 & -0.00117 & -0.00098 \\
\hline${ }^{95} \mathrm{Mo}(42095.80 \mathrm{c})$ & -0.00094 & -0.00095 & -0.0018 & -0.00149 \\
\hline${ }^{99} \mathrm{Tc}(43099.80 \mathrm{c})$ & -0.00211 & -0.00214 & -0.00367 & -0.0033 \\
\hline${ }^{101} \mathrm{Ru}(44101.80 \mathrm{c})$ & -0.00086 & -0.00068 & -0.00132 & -0.00125 \\
\hline${ }^{103} \mathrm{Rh}(45103.80 \mathrm{c})$ & -0.00645 & -0.00629 & -0.00976 & -0.00878 \\
\hline${ }^{109} \mathrm{Ag}(47109.80 \mathrm{c})$ & -0.001 & -0.0007 & -0.0016 & -0.00135 \\
\hline${ }^{133} \mathrm{Cs}(55133.80 \mathrm{c})$ & -0.00328 & -0.00306 & -0.00535 & -0.00475 \\
\hline${ }^{143} \mathrm{Nd}(60143.80 \mathrm{c})$ & -0.00887 & -0.00854 & -0.01338 & -0.01256 \\
\hline${ }^{145} \mathrm{Nd}(60145.80 \mathrm{c})$ & -0.00153 & -0.00144 & -0.00254 & -0.00235 \\
\hline${ }^{147} \mathrm{Sm}(62147.80 \mathrm{c})$ & -0.00109 & -0.00177 & -0.00193 & -0.00228 \\
\hline${ }^{149} \mathrm{Sm}(62149.80 \mathrm{c})$ & -0.01568 & -0.01515 & -0.01648 & -0.0152 \\
\hline${ }^{150} \mathrm{Sm}(62150.80 c)$ & -0.00085 & -0.00073 & -0.00152 & -0.00135 \\
\hline${ }^{151} \mathrm{Sm}(62151.80 \mathrm{c})$ & -0.00597 & -0.00451 & -0.00735 & -0.00519 \\
\hline${ }^{152} \mathrm{Sm}(62152.80 \mathrm{c})$ & -0.00198 & -0.00195 & -0.00303 & -0.00279 \\
\hline${ }^{151} \mathrm{Eu}(63151.80 \mathrm{c})$ & -0.00015 & -0.00117 & -0.00025 & -0.00143 \\
\hline${ }^{153} \mathrm{Eu}(63153.80 \mathrm{c})$ & -0.00158 & -0.00166 & -0.00305 & -0.00277 \\
\hline${ }^{155} \mathrm{Gd}(64155.80 \mathrm{c})$ & -0.00352 & -0.00669 & -0.00724 & -0.01316 \\
\hline
\end{tabular}

Note: MCNP = Monte Carlo N-Particle.

${ }^{a}$ Monte Carlo uncertainty is less than $0.00013 \Delta \mathrm{k}$ for FP\&MA worths. 



\begin{tabular}{|c|c|c|}
\hline BIBLIOGRAPHIC DATA SHEET & \multicolumn{2}{|c|}{$\begin{array}{l}\text { 1. REPORT NUMBER } \\
\text { (Asslgned by NRC. Add Vol., Supp., Rev., } \\
\text { and Addendum Numbers, If any.) } \\
\text { NUREG/CR-7205 } \\
\text { ORNL/TM-2012/544 }\end{array}$} \\
\hline \multirow{3}{*}{$\begin{array}{l}\text { 2. TITLE AND SUBTITLE } \\
\text { Bias Estimates Used in Lieu of Validation of Fission Products and Minor Actinides in MCNP } \\
\text { keff Calculations for PWR Burnup Credit Casks }\end{array}$} & \multicolumn{2}{|c|}{ 3. DATE REPORT PUBLISHED } \\
\hline & $\begin{array}{c}\text { MONTH } \\
\text { September }\end{array}$ & $\begin{array}{l}\text { YEAR } \\
2015\end{array}$ \\
\hline & \multicolumn{2}{|c|}{$\begin{array}{l}\text { 4. FIN OR GRANT NUMBER } \\
\text { J5728 }\end{array}$} \\
\hline \multirow[t]{2}{*}{$\begin{array}{l}\text { 5. AUTHOR(S) } \\
\text { D. E. Mueller, W. J. Marshall, D. G. Bowen, and J. C. Wagner }\end{array}$} & \multicolumn{2}{|c|}{$\begin{array}{l}\text { 6. TYPE OF REPORT } \\
\text { Technical }\end{array}$} \\
\hline & \multicolumn{2}{|c|}{ 7. PERIOD COVERED (Inclusive Dates) } \\
\hline \multicolumn{3}{|c|}{$\begin{array}{l}\text { 8. PERFORMING ORGANIZATION - NAME AND ADDRESS (If NRC, provide Division, Office or Region, U. S. Nuclear Regulatory Commission, and mailing address; if } \\
\text { contractor, provide name and mailing address.) } \\
\text { Oak Ridge National Laboratory } \\
\text { Managed by UT-Battelle, LLC } \\
\text { Oak Ridge, TN } 37831-6170\end{array}$} \\
\hline \multicolumn{3}{|c|}{$\begin{array}{l}\text { 9. SPONSORING ORGANIZATION - NAME AND ADDRESS (If NRC, type "Same as above", if contractor, provide NRC Division, Office or Region, U. S. Nuclear Regulatory } \\
\text { Commission, and mailing address.) } \\
\text { Division of Spent Fuel Management } \\
\text { Office of Nuclear Material Safety and Safeguards } \\
\text { U.S. Nuclear Regulatory Commission } \\
\text { Washington, DC 20555-0001 }\end{array}$} \\
\hline \multicolumn{3}{|l|}{ 10. SUPPLEMENTARY NOTES } \\
\hline \multicolumn{3}{|c|}{$\begin{array}{l}\text { 11. ABSTRACT (200 words or less) } \\
\text { The U.S. Nuclear Regulatory Commission Division of Spent Fuel Storage and Transportation issued Interim Staff Guidance (ISG) } 8 \text {, } \\
\text { Revision } 3 \text { in September } 2012 \text {. This ISG provides guidance for NRC Staff review of burmup credit analyses supporting transport and } \\
\text { dry storage of pressurized water reactor spent nuclear fuel (SNF) in casks. ISG-8, Rev. } 3 \text { includes, among other things, guidance for } \\
\text { addressing validation of criticality (keff) calculations crediting the presence of a limited set of fission products and minor actinides } \\
\text { (FP\&MA). Based on previous work documented in NUREG/CR-7109, ISG-8, Rev. } 3 \text { includes a recommendation to accept use of } 1.5 \\
\text { or } 3 \% \text { of the FP\&MA worth, depending on the criticality code and cross-section data used, to conservatively account for the bias and } \\
\text { bias uncertainty associated with the specified unvalidated FP\&MAs. This bias is applied in addition to the bias and bias uncertainty } \\
\text { resulting from validation of keff calculations for the major actinides in SNF. The work described in this report involves comparison } \\
\text { of FP\&MA worths calculated using SCALE and Monte Carlo N-Particle (MCNP) with Evaluated Nuclear Data Files, Part B-V, -VI, } \\
\text { and -VII based nuclear data. The comparison supports use of the 1.5\% FP\&MA worth bias when either SCALE or MCNP codes are } \\
\text { used for criticality calculations, provided the other conditions of ISG-8, Rev. 3, Recommendation } 4 \text { are met. The additional } \\
\text { conditions include that the cask design is similar to the hypothetical generic burnup credit-32 cask model and that the credited } \\
\text { FP\&MA worth is no more than } 0.1 \triangle \text { keff. }\end{array}$} \\
\hline \multirow{6}{*}{$\begin{array}{l}\text { 12. KEY WORDS/DESCRIPTORS (List words or phrases that will assist researchers in locating the report.) } \\
\text { Spent fuel } \\
\text { Criticality safety } \\
\text { Spent fuel transportation } \\
\text { Spent fuel dry storage } \\
\text { Burnup credit } \\
\text { ISG-8 }\end{array}$} & \multicolumn{2}{|c|}{$\begin{array}{c}13 \text { AVAILABILITY STATEMENT } \\
\text { Unlimited } \\
\end{array}$} \\
\hline & \multicolumn{2}{|c|}{ 14. SECURITY CLASSIFICATION } \\
\hline & \multicolumn{2}{|c|}{$\begin{array}{l}\text { (This Page) } \\
\text { unclassified }\end{array}$} \\
\hline & \multicolumn{2}{|c|}{$\begin{array}{l}\text { (This Report) } \\
\text { unclassified }\end{array}$} \\
\hline & \multicolumn{2}{|c|}{ 15. NUMBER OF PAGES } \\
\hline & \multicolumn{2}{|c|}{ 16. PRICE } \\
\hline
\end{tabular}




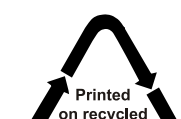

Printed
on recycled
paper

paper

Federal Recycling Program 



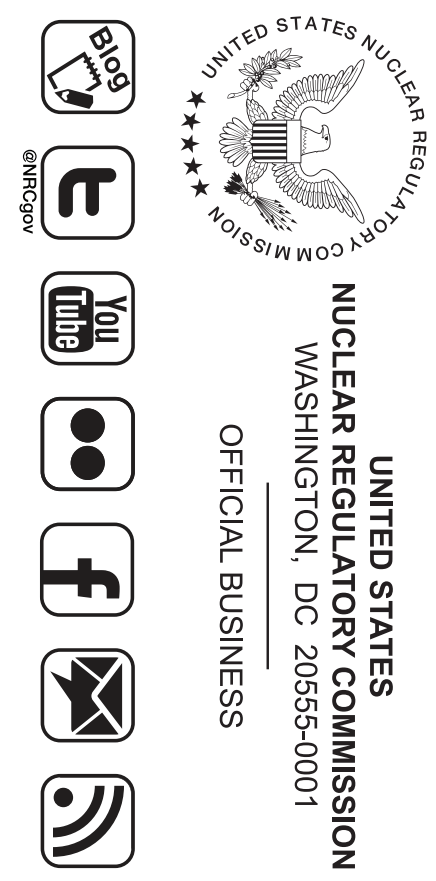



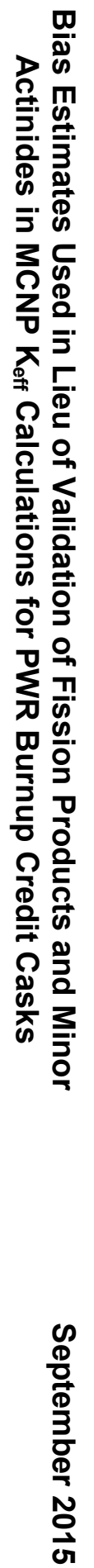